\title{
Epithelial cell expression of BCL-2 family proteins predicts mechanisms that regulate Helicobacter pylori-induced pathology in the mouse stomach
}

\author{
Susan J Hagen ${ }^{1}$, David X Yang ${ }^{1 *}$, Kimihito Tashima ${ }^{1 \dagger}$, Nancy S Taylor $^{2}$ and James G Fox ${ }^{2}$
}

Corpus-predominant infection with Helicobacter pylori (HP) results in the activation of programmed cell death pathways in surface, parietal, and chief cells. At present, mechanisms that regulate these pathways to result in $H P$-associated pathology are not fully understood. Because it is not known which survival and death pathways are present in gastric epithelial cells, we used an antibody panel to evaluate the expression of $\mathrm{BCL}-2$ family prosurvival proteins or multi-Bcl-2 homology (BH)-domains (group 1) or BH3-only (group-2) proapoptotic proteins in the stomachs of uninfected or $H P$-infected $\mathrm{C} 57 \mathrm{BL} / 6$ mice. This strategy identified $\mathrm{BCL}-2, \mathrm{BAK}$, and $\mathrm{BAD}$ as the major prosurvival and proapoptotic proteins, in surface cells and BAD as the only BCL-2 family protein expressed in parietal cells. Chief cells express altogether different effectors, including $B C L-X_{L} / B C L-2$, for survival but have no constitutively expressed proapoptotic proteins. In model chief cells, however, the group 1 proapoptotic protein $B C L-X_{S}$ was expressed after exposure to proinflammatory cytokines concomitant with reduced viability, demonstrating that chief cells can transcriptionally regulate the induction of proapoptotic proteins to execute apoptosis. During HP infection, no additional BCL-2 family proteins were expressed in epithelial cells, whereas those present either remained unchanged or were reduced as cell deletion occurred over time. Additional studies demonstrated that the posttranslational regulation of BAD in surface and parietal cells was negatively affected by HP infection, a result that may be directly related to an increase in apoptosis during infection. Thus, gastric epithelial cells express cell-specific prosurvival and proapoptotic pathways. From the results presented here, mechanisms that regulate $H P$-related changes in the survival and death profile of gastric epithelial cells can be predicted and then tested, with the ultimate goal of elucidating important therapeutic targets to inhibit the progression of $H P$-related pathology in the stomach.

Laboratory Investigation (2008) 88, 1227-1244; doi:10.1038/labinvest.2008.84; published online 8 September 2008

KEYWORDS: apoptosis; BAD; BCL-X; gastric

Programmed cell death $(\mathrm{PCD})$ in the stomach regulates the rate of epithelial cell turnover and is accelerated during $\mathrm{He}$ licobacter pylori $(H P)$ infection in humans and in animal models. Surface and pit epithelial cells, which are normally replaced every 3-4 days, show a significant increase in PCD during $H P$ or Helicobacter felis $(H F)$ infection in mice where dying cells can be visualized by TUNEL staining or caspase- 3 localization to extend from the surface deep into the gastric neck. ${ }^{1,2}$ In culture, surface cells also die rapidly by PCD in the presence of $H P$ - or $H F$-induced factors like ammonia, CagA, or gastrin. ${ }^{3-6}$ The death of parietal and chief cells, resulting in atrophy of gastric glands, may also occur by PCD, but this has been more difficult to document in vivo because of macrophages or other phagocytic cells that delete the dying cells. In isolated cell cultures, containing highly purified parietal or chief cells, or in gastric glands, containing mostly parietal and chief cells, PCD can be documented in the presence of ammonia, $H P$, or proinflammatory $\mathrm{T}_{\mathrm{H}^{-}}$cytokines by DNA laddering, caspase activation, and morphology. ${ }^{7-10}$ Although there is overwhelming support for the idea that PCD is important in the pathogenesis of HP infection and is instrumental in facilitating gastric atrophy and cancer

\footnotetext{
${ }^{1}$ Department of Surgery, Beth Israel Deaconess Medical Center, Boston, MA, USA and ${ }^{2}$ Division of Comparative Medicine, Massachusetts Institute of Technology, Cambridge, MA, USA

Correspondence: Dr SJ Hagen, PhD, Department of Surgery, E/DA-805, Beth Israel Deaconess Medical Center, 330 Brookline Avenue, Boston, MA 02215, USA.

${ }^{\dagger}$ Current address: Laboratory of Pharmacology, Faculty of Pharmaceutical Science, Josai International University, Chiba 283-8555, Japan.
} 
progression, little is known about the regulators of PCD or whether gastric epithelial cells undergo classical apoptosis, apoptosis-like PCD, or other forms of cell death. Most studies concerning apoptosis and HP infection use cancer cell lines that express numerous overlapping survival and death pathways, which may or may not be present in native gastric epithelial cells.

Proteins of the BCL-2 family are essential regulators of apoptosis, which is one of many types of PCD. ${ }^{11}$ Prosurvival members of the BCL-2 family in mammals, including BCL-2, BCL- $\mathrm{X}_{\mathrm{L}}, \mathrm{BCL}-\mathrm{W}, \mathrm{Mcl}-1, \mathrm{A1}, \mathrm{BOO} / \mathrm{DIVA} / \mathrm{Bcl}-2-10$, and BCL$\mathrm{B}$, contain four characteristic Bcl-2 homology (BH)-domains (BH1-BH4) and protect cells from death by binding to mitochondria and other intracellular membranes to inhibit the release of cytochrome $c$ or other activators of caspase activity. ${ }^{11-15}$ In contrast, proapoptotic proteins are in two groups. Group 1 proteins, including $\mathrm{BAX}, \mathrm{BAK}, \mathrm{BCL}-\mathrm{X}_{\mathrm{S}}$, BOK/MTD and BCL-GL, contain two or three BH domains. Group 2, or BH3-only proteins, including BAD, BIK/NBK, BID, Hrk/DP5, Blk, BMF, NOXA, PUMA/BBC-3, have only a 9-16 amino-acid BH3 domain. ${ }^{12,13}$ To execute the classical form of apoptosis, group 1 proteins are activated by $\mathrm{BH} 3$ only proteins (sensitization or an activation event), to result in oligomer formation, membrane pore formation, and the release of mitochondrial-associated apoptosis activators. ${ }^{11,14-16}$ Alternatively, BH3-only proteins may bind to and block the anti-apoptotic activity of prosurvival proteins to facilitate the activation of group 1 proteins without direct BH3-only protein interaction. ${ }^{15,17}$ Whichever mechanism prevails, these studies strongly support the notion that at least one BCL-2 family protein acts to support cell survival and at least one group 1 and one $\mathrm{BH} 3$-only proapoptotic protein must be present to execute apoptosis. Other forms of PCD, including apoptosis-like PCD, autophagy, or parapoptosis may or may not utilize BCL-2 family proteins to execute cell death. ${ }^{11}$

Because the regulation of some BCL-2 family proteins is now understood at the molecular level, it is possible to predict how cells maintain homeostasis and what factors contribute to the activation of cell death when specific proteins are expressed. For instance, $b c l-x$ gene expression is regulated transcriptionally by factors that facilitate expression of either the prosurvival or proapoptotic isoforms $\mathrm{BCL}-\mathrm{X}_{\mathrm{L}}$ and $-\mathrm{X}_{\mathrm{S}}$, respectively. ${ }^{18-20} \mathrm{BCL}-\mathrm{X}_{\mathrm{L}}$ is thought to inhibit opening of the mitochondrial permeability transition pore, which blocks the loss of mitochondrial membrane potential and the leakage of cytochrome $c$ that occurs after an apoptotic signal. ${ }^{21}$ BCL- $\mathrm{X}_{\mathrm{L}}$ may also bind directly to cytochrome $c$, thus inhibiting caspase activation and apoptosis. ${ }^{22}$ BCL- $\mathrm{X}_{\mathrm{S}}$ antagonizes cell death inhibition by binding to both BCL- $\mathrm{X}_{\mathrm{L}}$ and BCL-2. ${ }^{23}$ For homeostasis, the ratio of $\mathrm{BCL}-\mathrm{X}_{\mathrm{L}}$ to $-\mathrm{X}_{\mathrm{S}}$ expression is maintained in cells by sex steroids ${ }^{24,25}$ and glucocorticoids, ${ }^{26-28}$ whereas either inhibiting $\mathrm{BCL}-\mathrm{X}_{\mathrm{L}}$ or stimulating $-\mathrm{X}_{\mathrm{S}}$ expression facilitates apoptosis. ${ }^{21,29}$ In contrast, $\mathrm{BAD}$ is posttranslationally regulated by phosphorylation, where phospho-BAD is an inactive and nonphosphorylated $\mathrm{BAD}$ is an active proapoptotic protein. ${ }^{30-32}$ The ligation of receptors for growth and survival factors increase AKT, MAKP, ERK1/2 and PKA signaling pathways to phosphorylate BAD, ${ }^{30-35}$ and PP2A (and other phosphatases) actively dephosphorylate BAD to initiate apoptosis. ${ }^{36,37}$ When not phosphorylated, BAD forms heterodimers with protective BCL-2-family proteins to inactivate their prosurvival function at the mitochondrial membrane. ${ }^{38}$

During HP infection, mechanisms that facilitate survival and death of gastric epithelial cells, including surface, pit, parietal, and chief cells, is not clearly established, and the role of BCL-2-family prosurvival and proapoptotic proteins in the pathogenesis of $H P$ disease remains to be defined. Hence, the aim of this study was to characterize the expression of BCL2 -family prosurvival and proapoptotic proteins in control and $H P$-infected mice. From the results presented here, mechanisms that regulate $H P$-related changes in the survival and death profile of gastric epithelial cells can be predicted and then tested, with the ultimate goal of elucidating important therapeutic targets to inhibit the progression of HPrelated pathology in the stomach.

\section{MATERIALS AND METHODS \\ Animals}

Animals used for this study were maintained in accordance with the guidelines of the Committee on Animals at the Beth Israel Deaconess Medical Center and the Massachusetts Institute of Technology and those prepared by the committee on Care and Use of Laboratory Animals by the National Research Council. The studies were also conducted by approval from the IACUC Committee at each institution under approved protocols. C57BL/6 mice (female) that were free of Helicobacter spp., Citrobacter rodentium, Salmonella spp., endoparasites, and antibodies to viral pathogens were obtained from Taconic Farms (Germantown, NY, USA). The mice were housed in microisolator caging within an AAALAC-accredited facility.

\section{Bacteria}

$H P$ (Sydney) used for oral inoculation were grown for $48 \mathrm{~h}$ at $37^{\circ} \mathrm{C}$ under microaerobic conditions in $5 \%$ lysed horse blood agar as described by Lee et al. ${ }^{39}$ The bacteria were harvested after $48 \mathrm{~h}$ of growth, resuspended in PBS, assessed by Gram stain and phase microscopy for purity, morphology, and motility. In addition, the bacteria were tested for urease, catalase, and oxidase activity.

\section{Experimental Infection}

Eighteen mice (8 weeks old) were infected with $10^{8} \mathrm{CFU}$ of $H P$ in $0.3 \mathrm{ml}$ of PBS three times, every other day. Nine control mice were dosed with PBS only. At 6, 12, and 20 weeks postinfection (WPI), the stomach was excised from three control and 5-6 infected mice at each time point. Tissues from the antrum and corpus were taken for quantitative culture, histopathological evaluation, and 

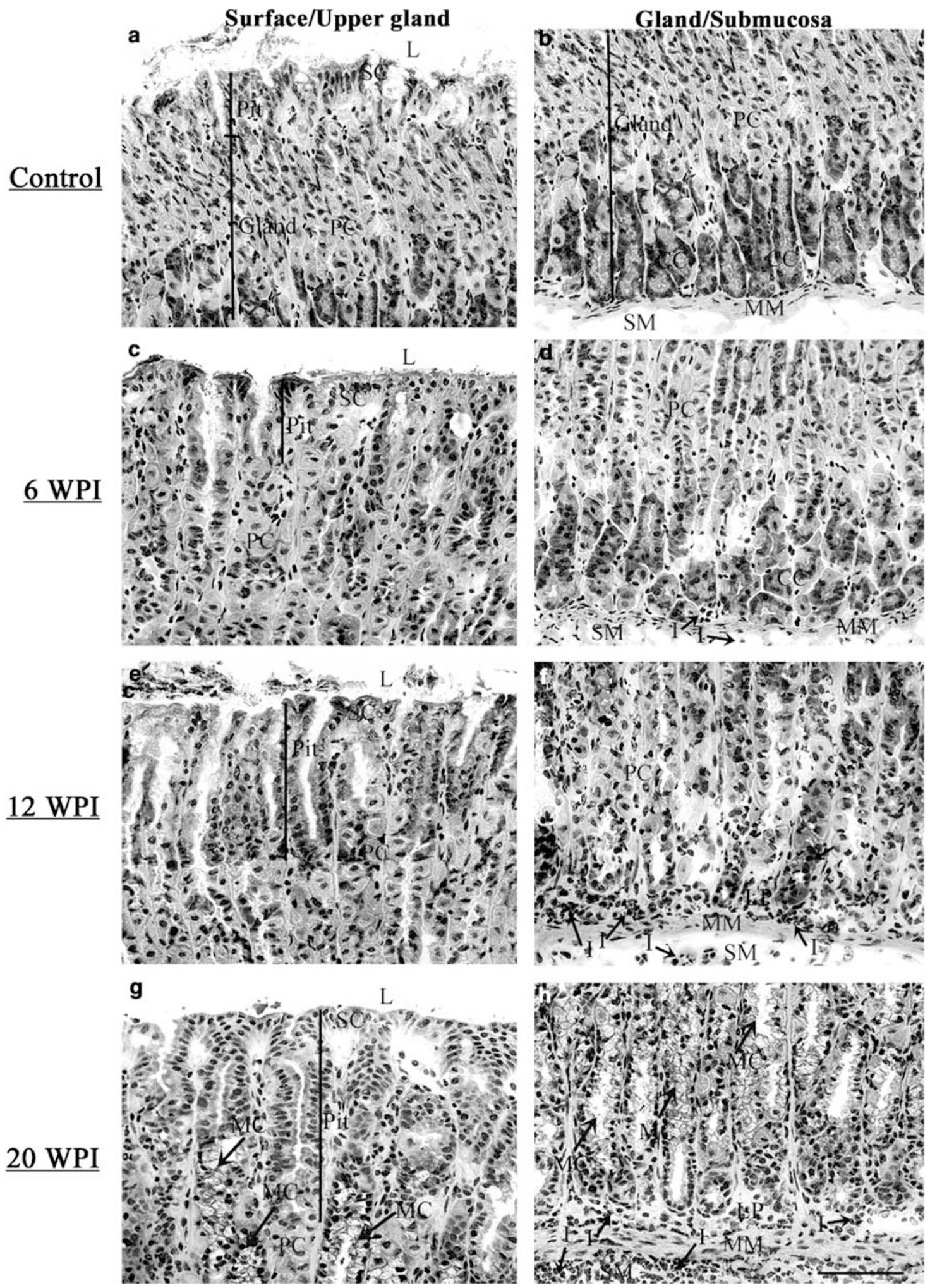

Figure 1 Morphology that was present in frozen sections from control tissues and at 6, 12 and 20 weeks postinfection (WPI) with HP that were used in subsequent immunostaining studies. On the left, images represent the surface, pit and upper gland region. On the right, images represent the middle and base of gastric glands, muscularis mucosa, and submucosa. Note that chief cells are nearly all deleted by 12 WPI (f) and that parietal and chief cells are replaced along the length of gastric glands by SPEM metaplastic cells (MCs) at 20 WPI ( $\mathbf{g}, \mathbf{h})$. Inflammation, identified by inflammatory cells in the lamina propria and submucosa, and hyperplasia, identified by lengthening of gastric pits, increased significantly over time (c-h). CC, chief cells; l, inflammatory cells; L, gland lumen; MM, muscularis mucosa; PC, parietal cells; SC, surface cells; SM, submucosa. Bar in $\mathbf{h}$ represents the magnification for images a-h and is $100 \mu \mathrm{m}$. 
immunocytochemistry. The original experiment was repeated one time with three control mice and 5-6 infected mice per time point and the data from like experimental groups were pooled.

\section{Quantitative Culture}

Quantitative culture was carried out as described by Fox et $a l^{40}$ using tissues from the antrum to verify infection. Although not discussed further, all $H P$-infected mice were colonized with $H P$ and those sham infected were not colonized with $H P$.

\section{Histopathological Evaluation}

The tissues examined consisted of a section taken from the lesser curvature to the middle of the stomach, beginning at the squamocolumnar junction and ending at the gastroduodenal junction. Stomach tissues were fixed in $10 \%$ neutral buffered formalin, processed, and then embedded in paraffin by standard methods. Tissues were sectioned and stained with hematoxylin and eosin. The corpus region of the stomach was examined histologically for inflammatory and epithelial changes consisting of (1) inflammation, (2) hyperplasia/mucoid metaplasia, and (3) parietal cell atrophy. Tissues were graded on an ascending scale ranging from 0 (normal) to 4 (marked). Tissues given a score of 1 contained rare, small, or a single focal mild lesion. Tissues given a score of 2 contained mild infiltrates or changes within limited regions with no inflammatory extension into the submucosa. Tissues given a score of 3 contained significant mucosal changes over a moderately sized, rather than limited, area with significant inflammatory extension into the submucosa. Tissues scored 4 contained extensive marked mucosal changes over extensive areas and marked inflammatory involvement of the submucosa.

\section{Immunocytochemistry and Analysis by Confocal Microscopy}

Tissues used for analysis were taken from the lesser curvature to the middle of the stomach, beginning at the squamocolumnar junction and ending at the antrum. Tissues were frozen in OCT, without fixation, in isopentane cooled with liquid nitrogen. Five-micrometer sections were cut on a Leica CM 1850 cryostat (Leica Instruments Inc., Nussloch, Germany), adhered to Superfrost Plus slides (Fisher Scientific, Pittsburgh, PA, USA), fixed for $1 \mathrm{~min}$ in $80 \%$ acetone at room temperature, and then stored at $-80^{\circ} \mathrm{C}$ until use. Sections for DiOC6 (Molecular Probes) staining omitted the acetone fixation step. For immunostaining, frozen sections were incubated with gelatin(gel)-PBS $(2 \mathrm{mg} / \mathrm{ml}$ gelatin (Knox), $150 \mathrm{mmol} / \mathrm{l} \mathrm{NaCl}$, and $10 \mathrm{mmol} / \mathrm{l}$ phosphate buffer, $\mathrm{pH}$ 7.4) containing $5 \%$ normal serum (rabbit or goat depending on the specific antibody) and 5\% nonfat dry milk to block, washed with gel-PBS, and then incubated with affinity purified specific antibody (listed below) followed by rhodamine-labeled secondary antibody (all purchased from

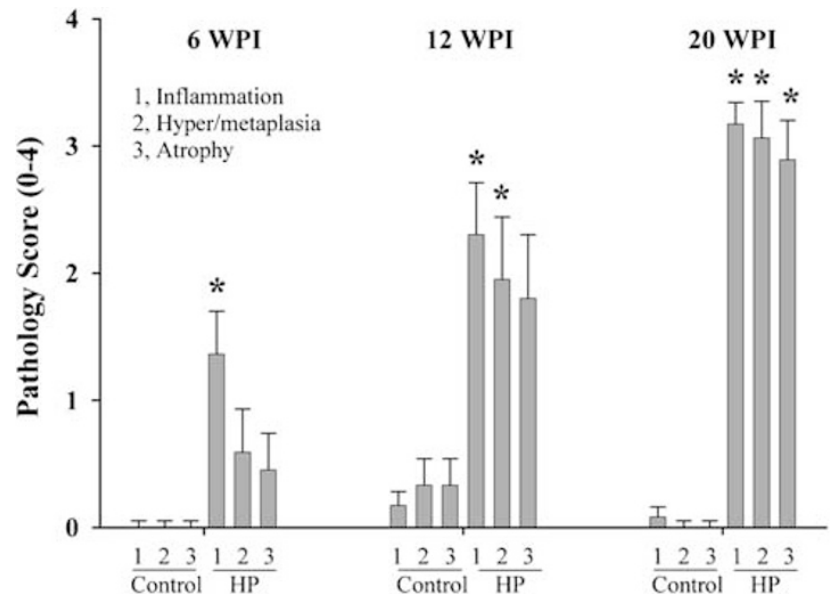

Figure 2 Quantification of progressive changes in inflammation, surface cell hyperplasia, intestinal metaplasia, and atrophy in the sum of tissues from Figure 1 that were used in this study. Pathology score evaluations of $0-4$ are described, in detail, in 'Materials and methods section'. * denotes a significant increase $(P<0.05)$ when compared to time-matched control tissues. Note that inflammation increases significantly as early as 6 WPI and that atrophy and metaplasia increase over time after $12 \mathrm{WPI}$. Infection results in a severe phenotype by $20 \mathrm{WPI}$.

Jackson Immunologicals). Tissues stained with DiOC6, to evaluate colocalization with membranes of mitochondria and the rough endoplasmic reticulum (rER), were carried out in the cold room in conjunction with the secondary antibody incubation step. Control and HP-infected tissues from a single experiment were stained, en mass, on the same day with one of the specific antibodies and then analyzed immediately after staining using a Zeiss LSM-510 META confocal laser system. Two images were taken for each tissue (from the corpus only); one near the squamocolumnar junction just distal to the cardia and one in the middle of the section. The intensity of staining was graded on an ascending scale ranging from 0 (no staining) to 4 (extremely strong staining) for the surface cell area, parietal cell area, and chief cell area, which were defined by using antibodies or probes specific for the cell type expected to be most prominent in the area including anti-Muc5A (Novocastra) for surface cells, Dolichos biflorus agglutinin (Sigma) for parietal cells, and anti-pepsinogen II (BioDesign) for chief cells. Grading was carried out by one of the authors (DX Yang) directly on the screen of the confocal microscope and then by another author (SJ Hagen) from images evaluated on the computer screen without foreknowledge of source. If expression was not apparent in the squamous nonglandular portion of the normal mouse stomach in pilot experiments, which was used as a positive control for many of the antibodies, positive staining in other tissues was established before staining the gastric mucosa in control and HP-infected mice. Blocking peptide (when available) was added to each primary antibody to test specificity and to set the background level for acquisition of images for each sample before analysis on the 

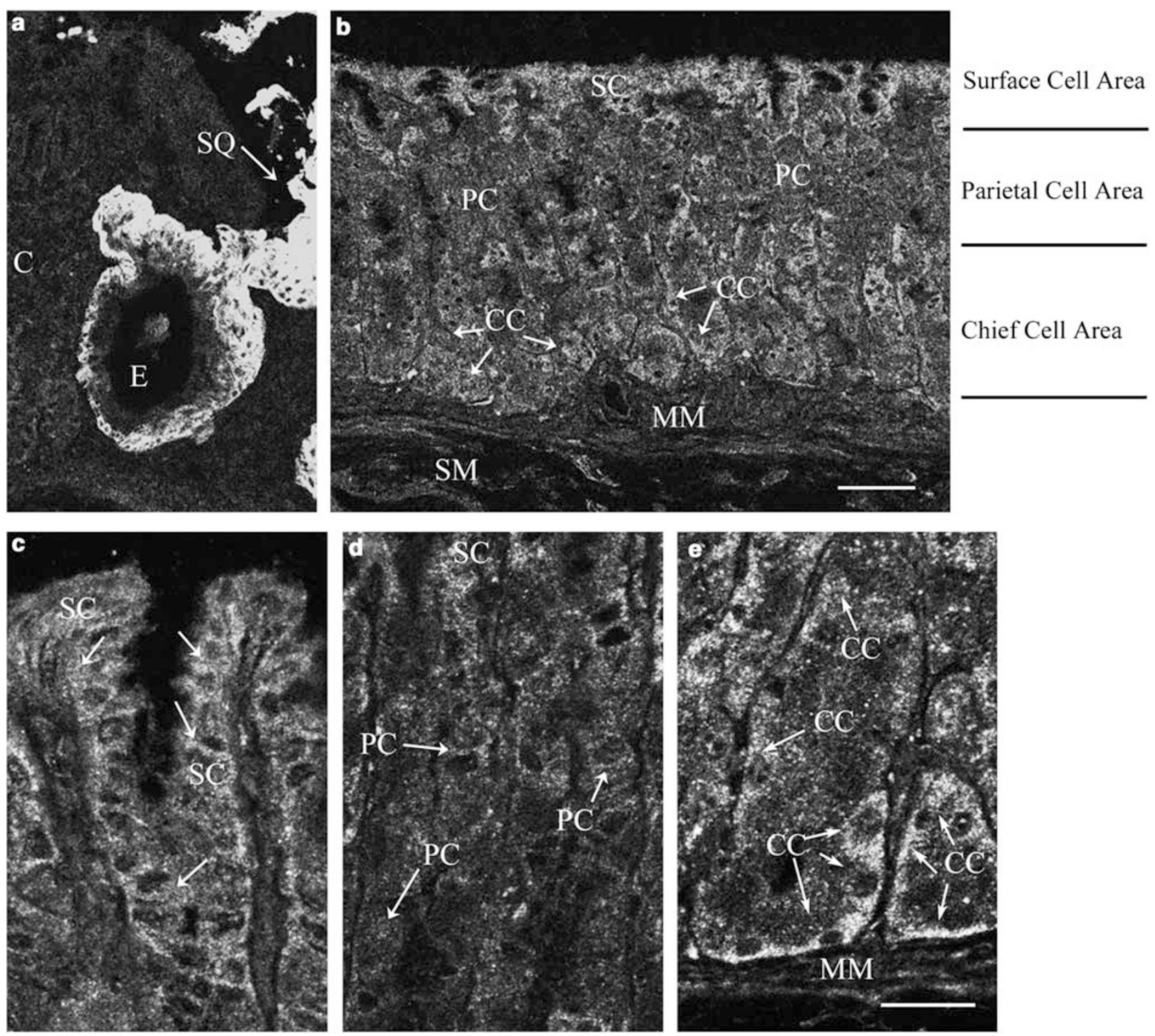

Figure 3 Expression of BCL-2 in sections of the stomach from control (untreated) mice. (a) BCL-2 expression is high in the squamous (SQ) epithelium of the esophagus (E) and nonglandular stomach and in much lower concentration in the corpus (C). (b) In sections that contain the entire mucosa, BCL-2 expression is found in surface cells (SCs) and in chief cells (CCs), but did not appear to be expressed above background levels in the parietal cells (PCs). (c) Expression of BCL-2 is found in the cytoplasm (arrows) of SCs. (d) In the parietal cell area, staining of individual parietal cells (arrows) was barely above background levels when compared to sections in which the primary antibody was not used (not shown). (e) In CCs, the expression of BCL-2 is strongest within the cytoplasm at the base of cells (arrows). L, lumen of a gastric gland; MM, muscularis mucosa; SM, submucosa. Bar in $\mathbf{b}$ represents the magnification for images $\mathbf{a}, \mathbf{b}$ and is $50 \mu \mathrm{m}$. Bar in e represents the magnification for images $\mathbf{c}-\mathbf{e}$ and is $20 \mu \mathrm{m}$.

confocal microscope-so that the negative control showed no specific background staining (a black image). The blocking peptides used were as follows and purchased from Santa Cruz Biotechnology Inc. (SC Santa Cruz, CA, USA) or from Cell Signaling Technology (Center St Jamaica Plain, MA, USA): (1) BCL-2, N-19 (SC); BCL-X $\mathrm{L} / \mathrm{S}$ L-19 (SC); BAD C-20 (SC); BAX, N-20 (SC), and BAD ${ }^{\text {ser112 }}$ (CST). Blocking peptideantibody staining solutions were prepared by adding a fivefold excess of blocking peptide by weight to the antibody, allowing interaction for a minimum of $2 \mathrm{~h}$ at room temperature, and then diluting the antibody to a final concentration, as discussed below. If blocking peptides were not available (anti-Bak, SC; anti-BAD, CST), the confocal background level was determined using second antibody alone. If results were negative in gastric mucosa but positive for a control tissue, whole stomach sample was also evaluated by western analysis and the results always confirmed the negative immunostaining results (not shown). The antibodies used and dilutions for immunostaining were as follows: (1) rabbit anti-BCL-2 (N-19; 1:50), (2) rabbit anti-BCL- $\mathrm{X}_{\mathrm{L} / \mathrm{S}}$ 
Table 1 Expression levels of prosurvival and proapoptotic proteins in the uninfected mouse stomach

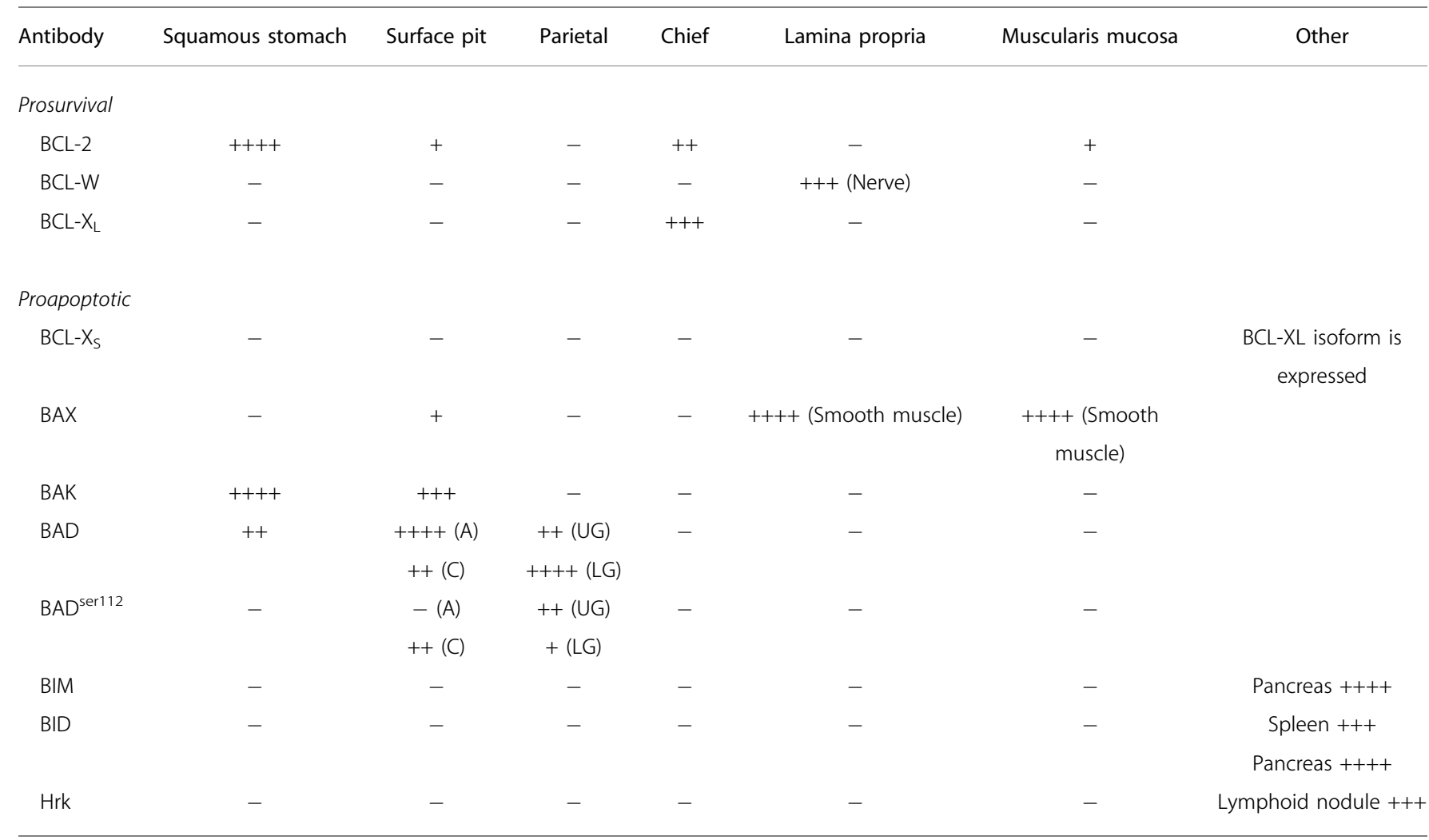

Weak level of expression (+); moderate level of expression (++); high level of expression (+++); extremely high level of expression (++++); no expression (-). A, expression at the apical surface; C, expression in the cytoplasm; UG, expression in upper glands; LG, expression in lower glands. The 'Other' category was used if no specific staining was obtained.

(L-19; 1:200), (3) goat anti-BCL-W (N-19; 1:50), (4) rabbit anti-BAX (P-19; 1:200), (5) rabbit anti-BAX (N-20; 1:200); (6) rabbit anti-BAD (C-20; 1:50), (7) rabbit anti-BAK (H-211; 1:50), (8) goat anti-BID (M-20; 1:50), (9) goat anti-Hrk (M-20; 1:100), and (10) goat anti-Bim (M-20; 1:50); all were purchased from Santa Cruz Biotechnology Inc. The expression of $\mathrm{BAX}, \mathrm{BAD}$, and $\mathrm{BAD}^{\text {ser112 }}$ was also determined by using rabbit anti-BAX $(554106 ; 5 \mu \mathrm{g} / \mathrm{ml})$ from BD Biosciences (Bedford, MA, USA), and rabbit anti-BAD $(9292 ; 1: 50)$ or rabbit anti-BAD ${ }^{\text {ser112 }}(9291 ; 1: 50)$ from Cell Signaling Technology. Colocalization of signal was evaluated by using Velocity software (Improvision, Lexington, MA, USA).

\section{Immunoblotting}

Mucosal scrapings from the mouse stomach (corpus) were prepared as described by us previously. ${ }^{41}$ K562 and chief cells in culture were solubilized in RIPA gel sample buffer containing $0.15 \mathrm{M} \mathrm{NaCl}, 1 \% \mathrm{NP}-40,0.5 \%$ SDS, $0.05 \mathrm{M}$ Tris $(\mathrm{pH}$ 8 ), $4 \mathrm{mM}$ EDTA, and one tablet of the complete mini protease inhibitor (Roche). After boiling, the protein concentration was determined and then proteins from each sample were separated by SDS-PAGE. The separated proteins were transferred to PDVF membranes (Bio-Rad) using a Bio-
Rad Trans-Blot semidry transfer cell, blocked with buffer containing nonfat dry milk, and then incubated with primary antibody. Bands were visualized by incubating with ${ }^{125} \mathrm{I}$ labeled protein A and autoradiography (whole stomach/ K562 cells) or by enhanced chemiluminescence (Amershamcultured chief cells).

\section{Cultured Chief Cells}

Isolated chief cells were prepared from the rat stomach (Sprague-Dawley; Taconic, Germantown, NY, USA) by density gradient and centrifugal elutriation techniques as described previously by others, ${ }^{8,42-46}$ and modified by us to obtain highly enriched chief cells. Enriched chief cells were plated at density of $2.9 \times 10^{5}$ cells per $\mathrm{cm}^{2}$ in collagen-coated Transwell plates and incubated in $5 \% \mathrm{CO}_{2}$ in air at $37^{\circ} \mathrm{C}$ in a 1:1 mixture of Ham's F-12 and Dulbecco's minimum essential medium, supplemented with heat-inactivated $10 \%$ fetal bovine serum, $8 \mu \mathrm{g} / \mathrm{ml}$ insulin, $1 \mu \mathrm{g} / \mathrm{ml}$ hydrocortisone, $100 \mathrm{U} / \mathrm{ml}$ penicillin, $100 \mathrm{U} / \mathrm{ml}$ streptomycin, $0.25 \mu \mathrm{g} / \mathrm{ml}$ amphotericin $\mathrm{B}$, and $100 \mathrm{ng} / \mathrm{ml}$ of hepatocyte growth factor. After the cells were confluent, hepatocyte growth factor and hydrocortisone were withdrawn overnight. Cytomix, 100\% of a stock cytokine mixture containing $10 \mathrm{ng} / \mathrm{ml}$ each of IFN $-\gamma$, TNF- $\alpha$, and IL- $1 \beta$, was then added to the basolateral chamber 

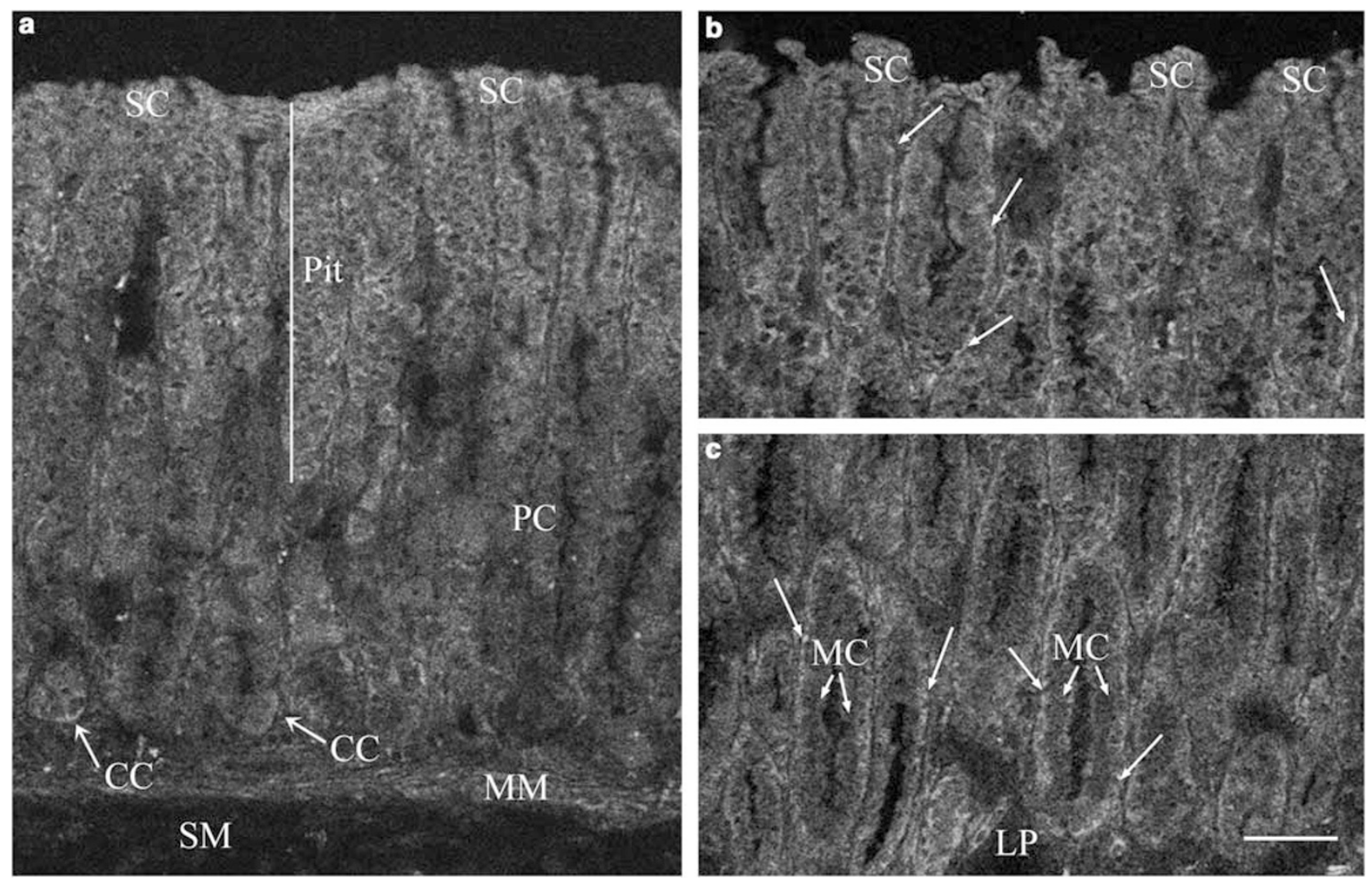

Figure 4 Expression of BCL-2 in sections from mice infected with HP. (a) At 12 WPI, there was lengthening of gastric pits (Pit) and hyperplasia of surface cells (SCs) so that the expression of BCL-2 was increased overall in this location. Although chief cells (CCs) were nearly deleted at $20 \mathrm{WPI}$, the few remaining contained BCL-2. (b) At 20 WPI, SCs expressed BCL-2, but the localization was mostly limited to the base of cells (arrows) and the cytoplasmic localization (asterisk) was not present. (c) At $20 \mathrm{WPI}$, metaplastic cells (MCs) that occupy the gastric glands (refer to Figure $1 \mathrm{~h}$ ) expressed BCL-2 in the basal cytoplasm (arrows). LP, lamina propria; MM, muscularis mucosa; SM, submucosa. Bar in c represents the magnification for images $\mathbf{a}, \mathbf{b}$ and is $50 \mu \mathrm{m}$.

of chief cell cultures. Viability was measured by using the crystal violet assay, as described previously by us. ${ }^{6}$

\section{Statistical Analysis}

Combined data were expressed as mean \pm s.e. Statistical analysis of data were carried out with SigmaStat software (Jandel Scientific Software, San Rafael, CA, USA) using the unpaired $t$-test for analysis of two groups or one-way analysis of variance for many groups. Differences were regarded as statistically significant at $P<0.05$.

\section{RESULTS}

\section{HP (Sydney) Infection in the Mouse Stomach}

To establish an HP model in the mouse stomach that was suitable for the analysis of cell survival and death protein expression, we infected mice with HP (Sydney strain, SS1) and evaluated the histology in conventional paraffin and frozen sections at a number of time points after infection (Figures 1 and 2). Of interest was to establish three conditions for analysis. First, an early time point that showed little histological change after infection, which occurred at 6 WPI (Figures $1 \mathrm{c}, \mathrm{d}$ and 2). The rationale for this time point was to evaluate tissues before the deletion of gland epithelial cells, perhaps allowing detection of changes in protein expression that would facilitate cell death and atrophy in this model. For the latest time point, which occurred at 20 WPI (Figures 1g, h and 2), our aim was to have tissues that showed the hallmarks of HP infection including (1) lengthening of gastric pits with concomitant surface cell hyperplasia, (2) deletion of chief and parietal cells resulting in gland atrophy, (3) replacement of corpus glandular cells with spasmolytic polypeptide-expressing metaplasia (SPEM) cells, and (4) severe inflammation, especially at the base of gastric glands. For the middle time point (Figures 1e, f and 2), we sought an intermediate phenotype, which occurred at 12 WPI. In all cases the stomach corpus from control, sham infected, mice at 6, 12, and 20 WPI had normal histology (Figures 1a, b and 2).

\section{BCL-2 and BCL-X Expression in Mouse Stomach}

In contrast to the high level of expression of BCL-2 in the nonglandular stomach and esophagus (Figure 3a; Table 1), BCL-2 expression was far less evident in epithelial cells from the corpus (Figure 3a) and was limited to surface, pit, and chief cells (Figure $3 \mathrm{~b}$; Table 1). In surface and pit cells, the 
localization of BCL-2 was throughout the cell cytoplasm with notable density along the basal and lateral membranes whereas in chief cells it was concentrated at the base of cells, which is the area known to contain rER and mitochondria and to be devoid of secretory granules (Figure $3 c$ and e). For parietal cells, there was weak signal for BCL-2 in both stained a

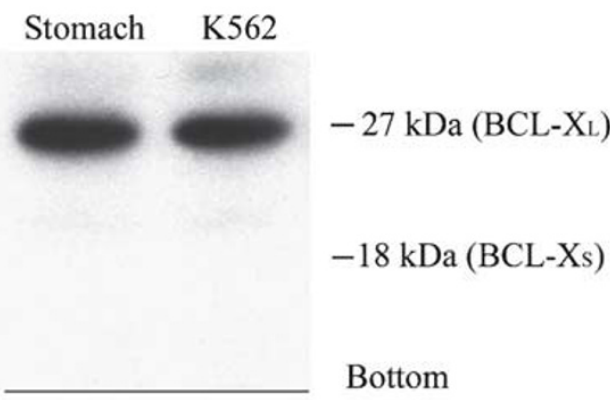

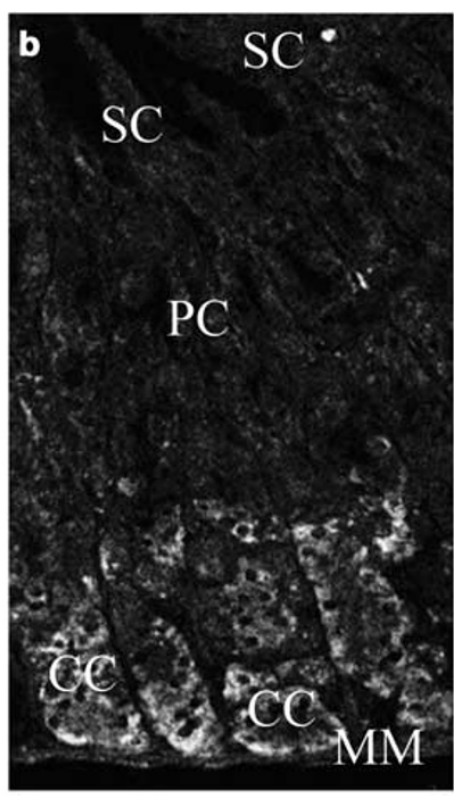
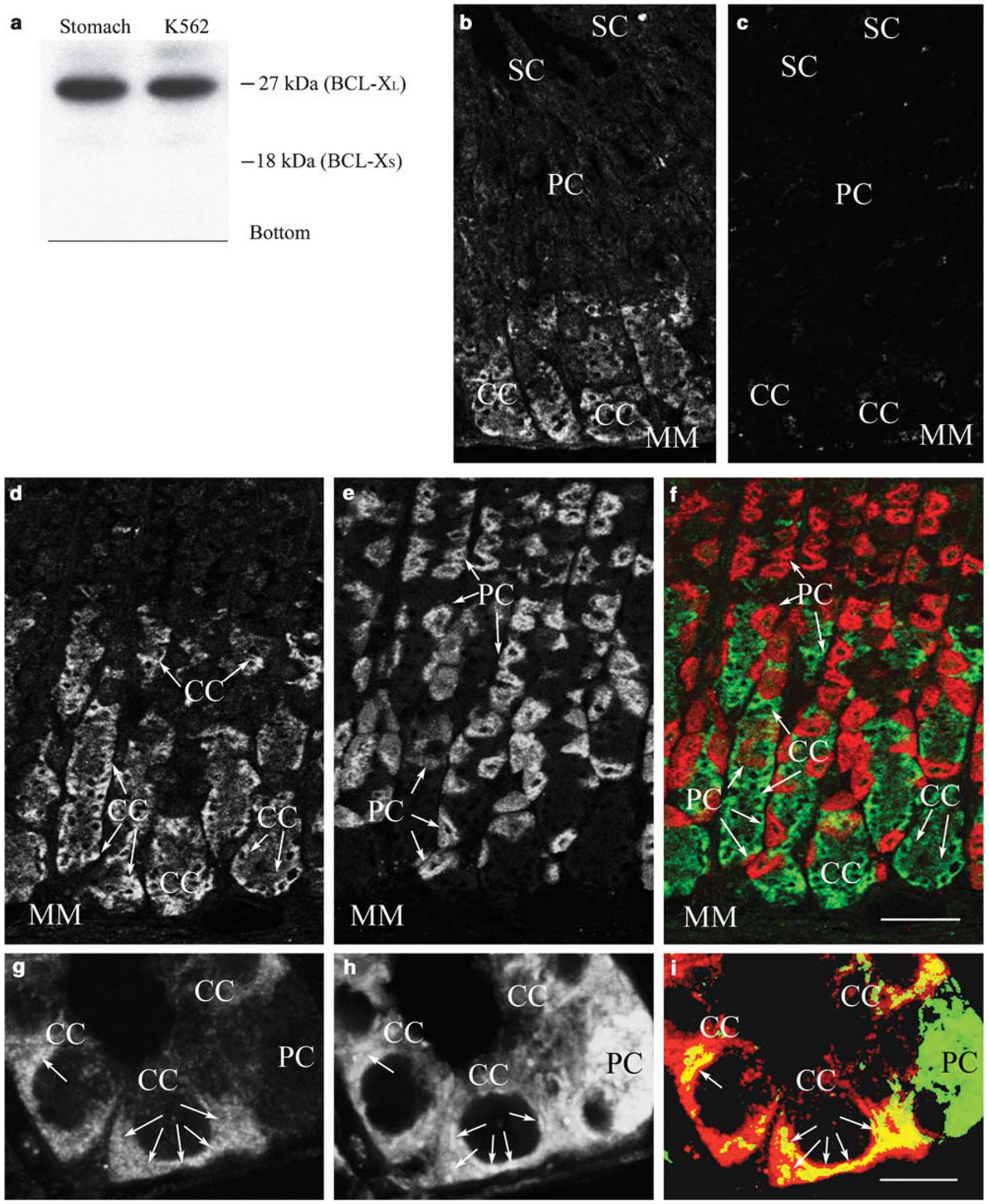
and control tissues suggesting that, if present, BCL-2 expression in parietal cells is below detection limits of the immunostaining procedure (Figure $3 \mathrm{~d}$ ).
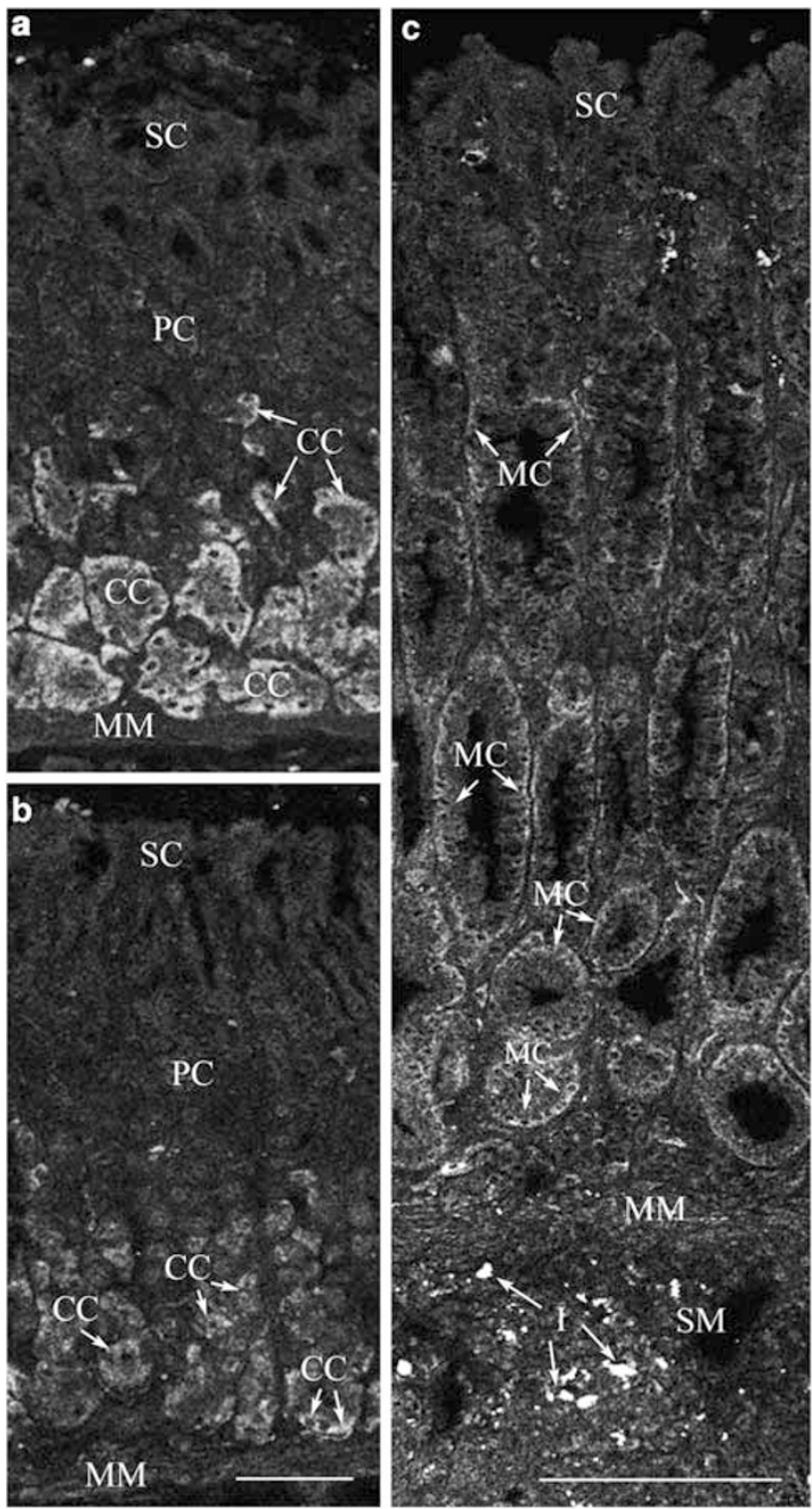

In HP-infected mice at 6 WPI, the expression of BCL-2 was the same as in control tissues (not shown). At 12 WPI, the expression of BCL-2 in surface and pit cells was unchanged but lengthening of gastric pits containing BCL-2 positive cells was evident (Figure 4a). Although few chief cells were present at $12 \mathrm{WPI}$, those remaining were positive for BCL-2 (Figure 4a). At 20 WPI, BCL-2 localization in surface cells was restricted to the basal cytoplasm and the intracellular expression was greatly reduced (Figure 4b). BCL-2 was also expressed in SPEM cells (Figure 4c), and in inflammatory cells (not shown) at 6,12 and 20 WPI.

Although BCL-W was expressed in cells of the lamina propria, it was not expressed in epithelial cells in control or in HP-infected mice (Table 1). As such, BCL-X was the only other prosurvival BCL-2 family protein we tested that was expressed in the corpus mucosa (Table 1). Because antibodies to $\mathrm{BCL}-\mathrm{X}$ recognize both the $27 \mathrm{kDa}$ long $\left(\mathrm{BCL}-\mathrm{X}_{\mathrm{L}}\right.$, prosurvival) and $18 \mathrm{kDa}$ short (BCL- $\mathrm{X}_{\mathrm{S}}$, proapoptotic) isoforms of the $b c l-x$ gene, we used solubilized mucosal scrapings from the stomach and performed western blotting to demonstrate that the $27 \mathrm{kDa}$ prosurvival $\mathrm{BCL}-\mathrm{X}_{\mathrm{L}}$ isoform is constitutively expressed in the stomach (Figure 5a). K562 cells, which express $\mathrm{BCL}-\mathrm{X}_{\mathrm{L}}$, were used to confirm the molecular weight (Figure 5a).

In the corpus region from all control mice, BCL-X localized specifically to chief cells (Figure $5 \mathrm{~b}$ and c; Table 1). Because some parietal cells reside at the base of gastric glands in close proximity to chief cells, it was unclear if parietal cells

Figure 6 Expression of BCL-X in tissues from mice infected with $H P$ at 6 (a), 12 (b), and 20 (c) WPI. (a) At 6 WPI, the expression of BCL-X was the same as in control tissues and confined to the base of gastric glands in chief cells (CCs). Surface cells (SCs) and parietal cells (PCs) did not express BCL-X. (b) At $12 \mathrm{WPI}$, the expression of BCL-X was significantly attenuated, because of deletion of CCs from the base of gastric glands. However, the remaining CCs showed high to moderate expression of BCL-X. (c) At 20 WPI, SPEM metaplastic cells (MCs) show weak to moderate expression for BCL-X only at the base of cells. Note that inflammatory cells (I) also expressed high levels of BCL-X. MM, muscularis mucosa; SM, submucosa. Bar in $\mathbf{b}$ represents the magnification for images $\mathbf{a}, \mathbf{b}$ and is $50 \mu \mathrm{m}$. The bar in $\mathbf{c}$ is also $50 \mu \mathrm{m}$.

Figure 5 Expression of BCL-X in tissue samples from control (untreated) mice. (a) By gel electrophoresis and western blotting, the $27 \mathrm{kDa}$ form of $\mathrm{BCL}-\mathrm{X}$, $\mathrm{BCL}-\mathrm{X}_{\mathrm{L}}$, is the predominant isoform in the gastric mucosa. Mucosal scrapings from the stomach were compared to cultured K562 cells, a cell line that constitutively expresses BCL- $X_{L}$. (b, c) Full-length tissue samples (serial sections) showing the specificity of antibody staining for BCL- $\mathrm{X}_{\mathrm{L} / \mathrm{s}}$ to chief cells (CCs). Note that when using blocking peptide (c), CC expression is negative and the image is black. This figure is an example of how the confocal was set to acquire all of the specific immunostaining images in this report. (d-f) Localization of BCL-X in tissue samples labeled with anti-BCL-X $\mathrm{L}_{\mathrm{L} / \mathrm{s}}$ antibody (d), Dolichos biflorus agglutinin for parietal cells (e), and merged images (f). Note that BCL-X is expressed only in CCs at the base of gastric glands (green-CC) and is not colocalized with parietal cells (red-PC), because no yellow color is present to indicate colocalization of the red and green signals. (g-i) High magnification images of CCs from the base of gastric glands in the mouse stomach stained with anti-BCL- $\mathrm{K}_{\mathrm{L} / \mathrm{s}}$ antibody (g) and with DiOC6 for cell membranes (h). Thresholding techniques were used to show colocalization of BCL-X (red-CC) with high intensity DiOC6 label (green-PC) that represents the localization of rER and mitochondrial membranes in CCs. The yellow signal represents areas of colocalization (arrows in $\mathbf{h}-\mathbf{i}$ ). Parietal cells (PCs) have numerous large mitochondria and were used to set the high intensity threshold for mitochondria and $r E R$ in $\mathbf{i}$. Bar in $\mathbf{f}$ represents the magnification for images $\mathbf{b}-\mathbf{f}$ and is $50 \mu \mathrm{m}$. Bar in $\mathbf{i}$ represents the magnification for images $\mathbf{g}-\mathbf{i}$ and is $20 \mu \mathrm{m}$. MM, muscularis mucosa. 
Table 2 Level of expression and number of cells in the mucosa that express prosurvival and proapoptotic BCL-2 family proteins at 6,12 , and 20 weeks postinfection (WPI) with Helicobacter pylori ${ }^{\text {a }}$

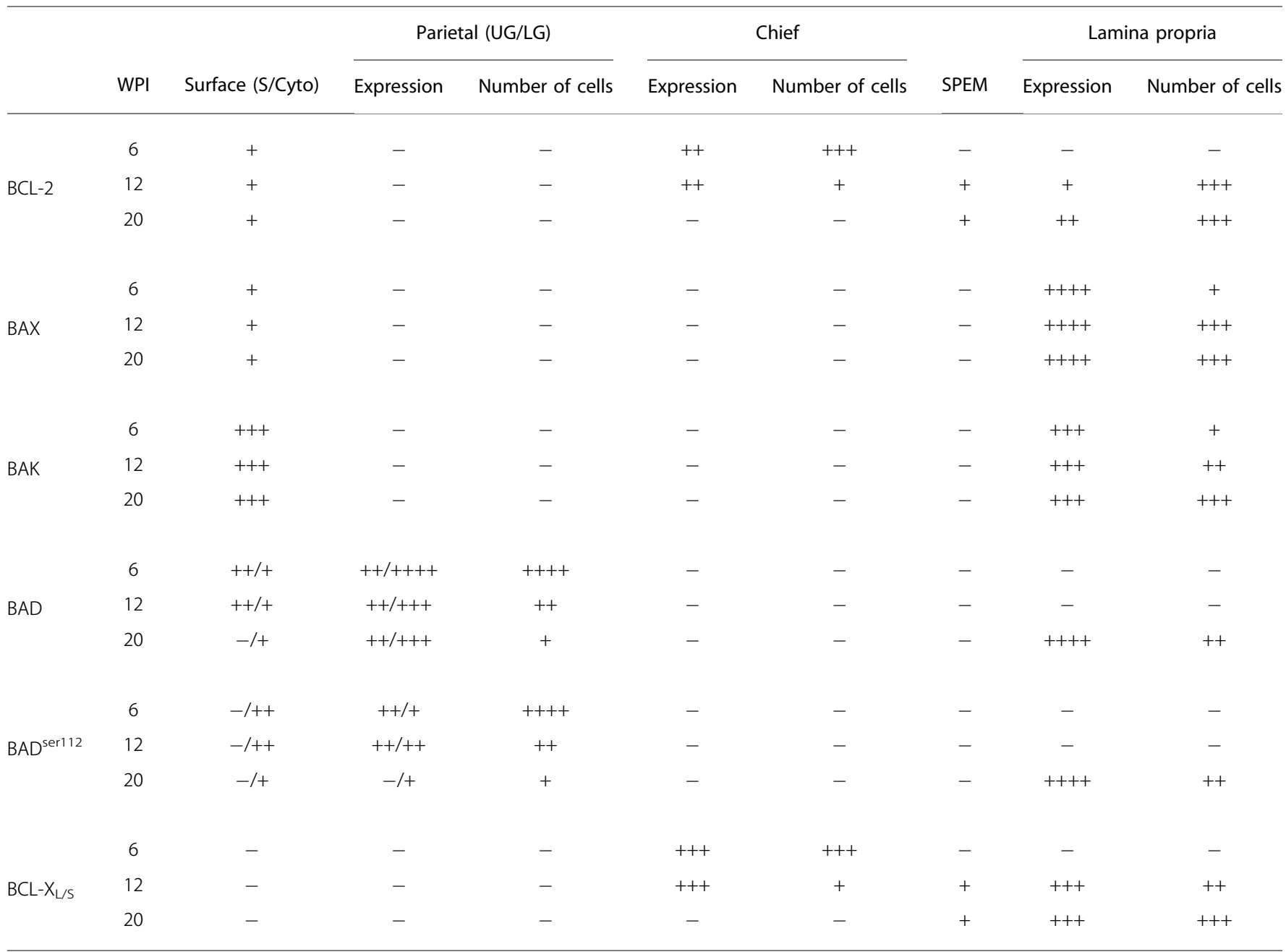

Low level of expression or number of cells because of $H P$-induced atrophy $(+)$; moderate level of expression or number of cells because of $H P$-induced atrophy $(++)$; high level of expression or normal compliment of cells with little to no HP-induced atrophy (+++); extremely high level of expression or number of cells $(++++)$; no expression or cells remaining because of HP-induced atrophy $(-)$. S, luminal surface expression; Cyto, expression limited to the cell cytoplasm; UG, expression in parietal cells of the upper gland; LG, expression in parietal cells of the lower gland.

${ }^{\mathrm{a}} \mathrm{BCL}-2, \mathrm{BAX}, \mathrm{BAK}, \mathrm{BID}, \mathrm{BIM}$, and Hrk were all present in inflammtory cells during HP infection.

in that location also express BCL-X. Therefore, tissues were stained with anti-BCL-X (Figure 5d) in combination with $D$. biflorus agglutinin, which specifically stains parietal cells from the mouse (Figure 5e), to confirm exclusive expression of BCL-X to chief cells. This conclusion was made because no yellow signal was present in the merged images of Figure $5 \mathrm{~d}$ and $\mathrm{e}$ to indicate colocalization with parietal cells (Figure 5f). In high magnification images from control tissues, BCL-X localized most strongly to the base of chief cells (Figure 5g) and was in association with intracellular membranes like mitochondria or rER. This conclusion was supported by costaining tissues with antiBCL-X (Figure 5g) and DiOC6 (Figure 5h) and evaluating the coincidence of signals by image processing in merged images (Figure 5i). Bright yellow signal was present, especially in the subnuclear region of chief cells, in the merged images to indicate colocalization of BCL-X with membranes (Figure 5i).

During HP infection, the expression of BCL-X at 6 WPI was the same as in control tissues (Figure 6a; Table 2). By 12 WPI, a considerable number of chief cells were deleted from gastric glands and the overall expression of BCL-X was significantly reduced (Figure 6b; Table 2). By 20 WPI, few to no chief cells were present in the mucosa so chief cell-specific staining for BCL-X was absent (Figure 6c; Table 2). However, SPEM cells along the length of gastric glands at 12 and 20 WPI expressed low levels of BCL-X along their basal surface (Figure 6c), a localization that is similar to that of BCL-2 in 

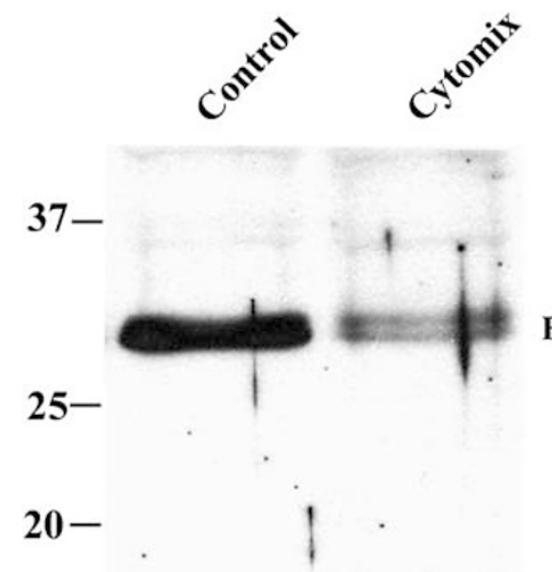

BCL-XL (27 kDa)

BCL-Xs (18kDa)
Figure $4 \mathrm{c}$. The ratio of BCL- $\mathrm{X}_{\mathrm{L}} /-\mathrm{X}_{\mathrm{S}}$ would not be detected in our immunostaining data for tissues infected with $H P$ because the antibody recognizes both isoforms of BCL-X. In addition, because immune cells also express BCL-X (Figure 6c; Table 2), data from whole stomach samples for western blots would not be informative about in vivo changes in ratio of BCL- $\mathrm{X}_{\mathrm{L}} / \mathrm{X}_{\mathrm{S}}$ in chief cells.

Because inflammation in $H P$-infection is robust at the base of gastric glands where chief cells reside (Figure $1 \mathrm{~d}, \mathrm{f}$, and $\mathrm{h}$ )

Figure 7 Expression of $\mathrm{BCL}-\mathrm{X}_{\mathrm{L} / \mathrm{S}}$ in cultured chief cells exposed for $48 \mathrm{~h}$ to no treatment (control) or to $100 \%$ cytomix (cytomix) containing $10 \mathrm{ng} / \mathrm{ml}$ each of IFN- $\gamma$, TNF- $\alpha$, and IL- $1 \beta$. Note that chief cells constitutively express high levels of the prosurvival protein $B C L-X_{L}$, which is reduced significantly in the presence of cytomix. In addition, cytomix induces the expression of the proapoptotic effector, $\mathrm{BCL}-\mathrm{X}_{\mathrm{S}}$. Cytomix concomitantly reduced the viability of cultured chief cells to $51.478 \pm 3.503 \%$ of control in $48 \mathrm{~h}$.
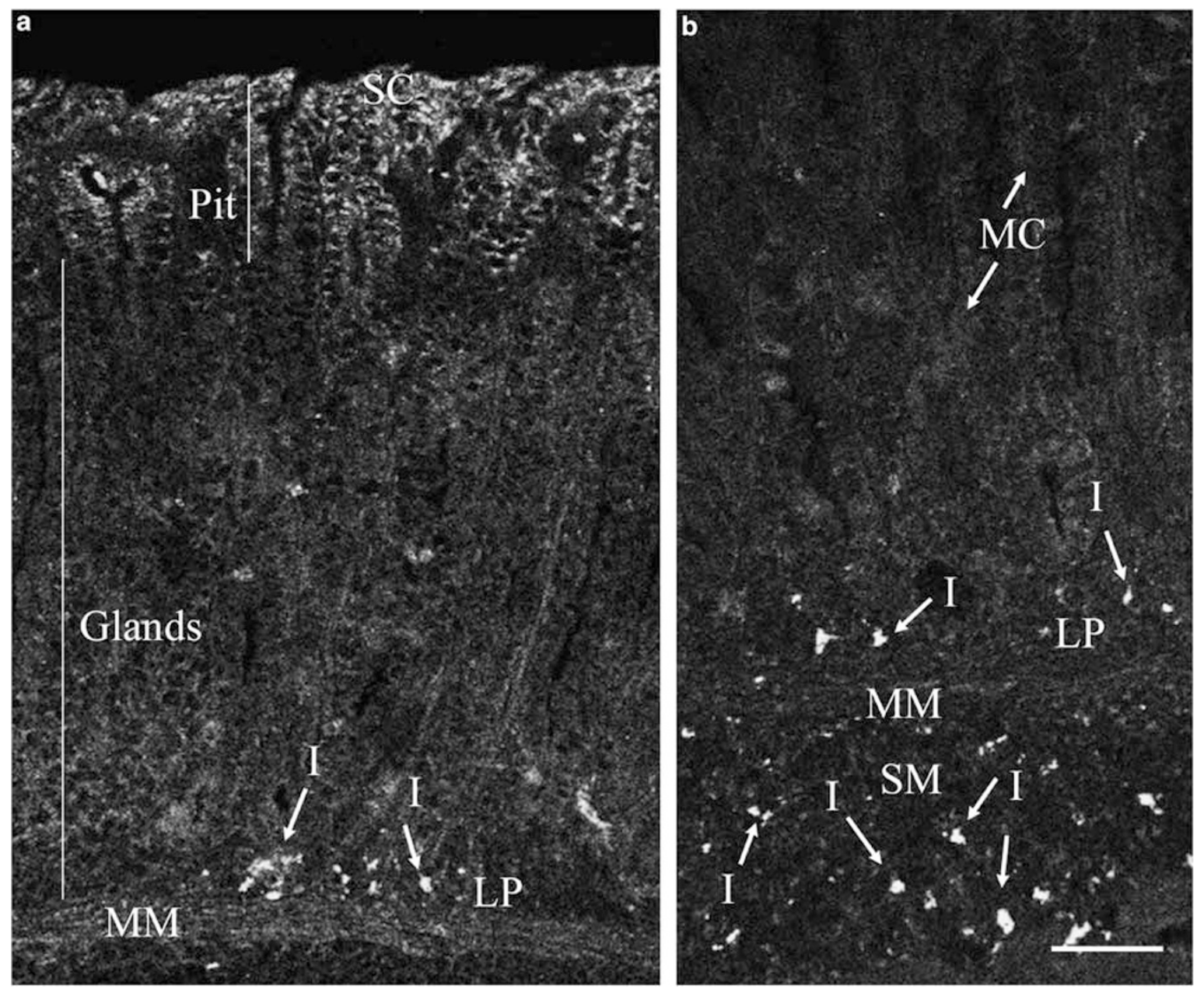

Figure 8 Expression of BAK in tissues from mice infected with HP at 12 (a) and 20 (b) WPI. (a) At 12 WPI, BAK was strongly expressed in surface cells (SCs) and extended the length of gastric pits (Pit). There was no expression over background in the gastric glands, containing parietal and chief cells. Inflammatory cells (I) in the lamina propria (LP) also strongly expressed BAK. (b) At 20 WPI, BAK expression remained strong in SCs (not shown) and was highly expressed in inflammatory cells in the LP and submucosa (SM). MM, muscularis mucosa. Bar in $\mathbf{b}$ represents the magnification for images $\mathbf{a}, \mathbf{b}$ and is $50 \mu \mathrm{m}$. 
and is associated with $\mathrm{T}_{\mathrm{H}^{-}} 1$ cytokines, we incubated cultured chief cells with cytomix, containing IFN- $\gamma$, TNF- $\alpha$, and IL- $1 \beta$, to determine whether $b c l-x$ expression can be transcriptionally regulated, in vitro. Interestingly, the viability of cultured chief cells was reduced to $51.478 \pm 3.503 \%$ of con- trol in $48 \mathrm{~h}$ with cytomix and this treatment also resulted in changes in the ratio of BCL- $\mathrm{X}_{\mathrm{L}} /-\mathrm{X}_{\mathrm{S}}$ (Figure 7). Although the prosurvival protein $\mathrm{BCL}-\mathrm{X}_{\mathrm{L}}$ was significantly reduced when compared to cells grown in control conditions, the expression BCL- $\mathrm{X}_{\mathrm{S}}$ was increased so that a distinct band at $18 \mathrm{kDa}$ was
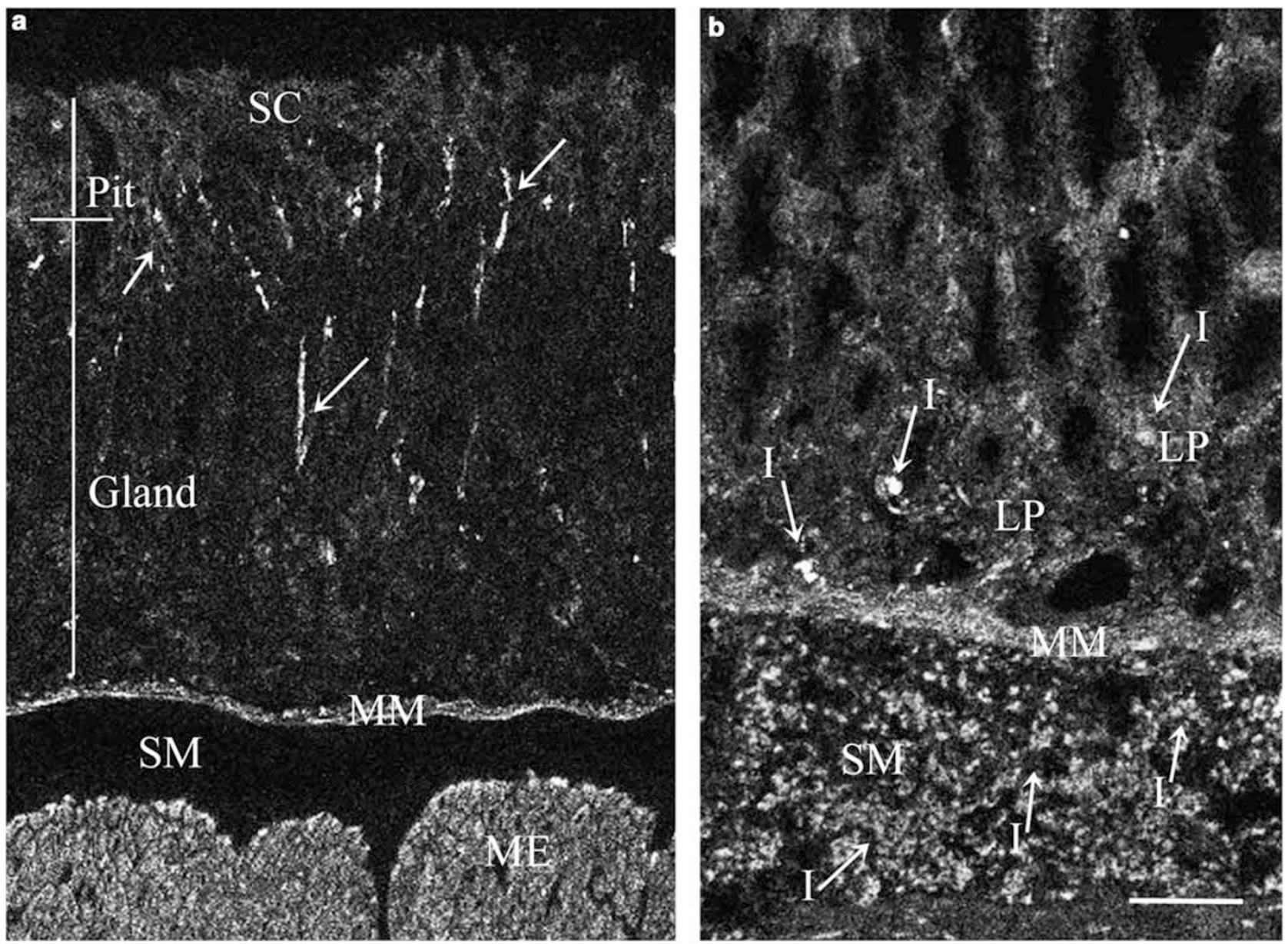

Figure 9 Expression of BAX in control tissues (a) and from mice infected with HP at 20 WPI (b). (a) In control tissues, BAX was weakly expressed in surface cells (SCs) but was strongly expressed in smooth muscle cells of the muscularis mucosa (MM) and external muscle (ME). There was also BAX expression in the lamina propria (LP), which may represent smooth muscle that is known to be present in the LP. There was little expression of BAX over background in the gastric gland, containing parietal and chief cells. (b) At 20 WPI, BAX remained weakly expressed in SCs (not shown) but was highly expressed in inflammatory cells (I) in the LP and submucosa (SM). MM, muscularis mucosa. Bar in $\mathbf{b}$ represents the magnification for images $\mathbf{a}, \mathbf{b}$ and is $50 \mu \mathrm{m}$.

Figure 10 Expression of BAD in sections from control mice (a) and from mice at 6 (b), 12 (c) and 20 (d) WPI. The expression of BAD ${ }^{\text {ser112 }}$ is also shown in an adjacent serial section from control mice (e) and at higher magnification (f). (a) The expression of BAD was in surface cells (SCs) and parietal cells (PCs) in the untreated gastric mucosa. In SCs, BAD was strongly expressed in the apical cytoplasm and was localized diffusely in the remaining cytoplasm. In PCs, BAD showed a pit-to-base gradient of expression where the signal for BAD was low in PCs just below the gastric pit and was extremely strong in some cells at the base of gastric glands. The expression of BAD in chief cells (CCs) was not above background levels as determined when using a secondary antibody alone (not shown). The box indicates the location of staining for BAD ${ }^{\text {ser112 }}$ in Figure 8e and f. (b) At 6 WPI, BAD expression was like control where it localized to both surface and PCs. BAD appeared to be reduced at the apical surface in both apical and cytoplasmic locations. (c) At 12 WPI, the expression of BAD in surface cells remained weak in apical and cytoplasmic locations but was present in all surface cells in the elongated gastric pit. In addition, the expression in PCs was reduced significantly, with strong expression only in a few cells at the base of gastric glands. (d) At 20 WPI, the apical expression of BAD in SCs was absent although cytoplasmic expression remained moderately strong. PCs, although few were remaining, retained the pit-to-base gradient expression of BAD. (e, $\mathbf{f}$ )

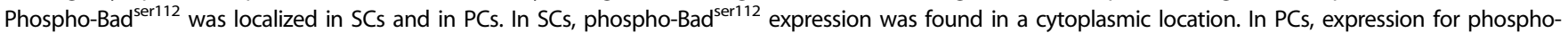
$\mathrm{Bad}^{\mathrm{ser} 112}$ was at the apical surface (arrows) with some expression in the cytoplasm (asterisks with arrows). This localization of Bad ${ }^{\text {ser112 }}$ occurred only in PCs from the upper neck. Bar in $\mathbf{d}$ represents the magnification for images a-e and is $50 \mu \mathrm{m}$. Bar in $\mathbf{f}$ is $20 \mu \mathrm{m}$. MM, muscularis mucosa. 

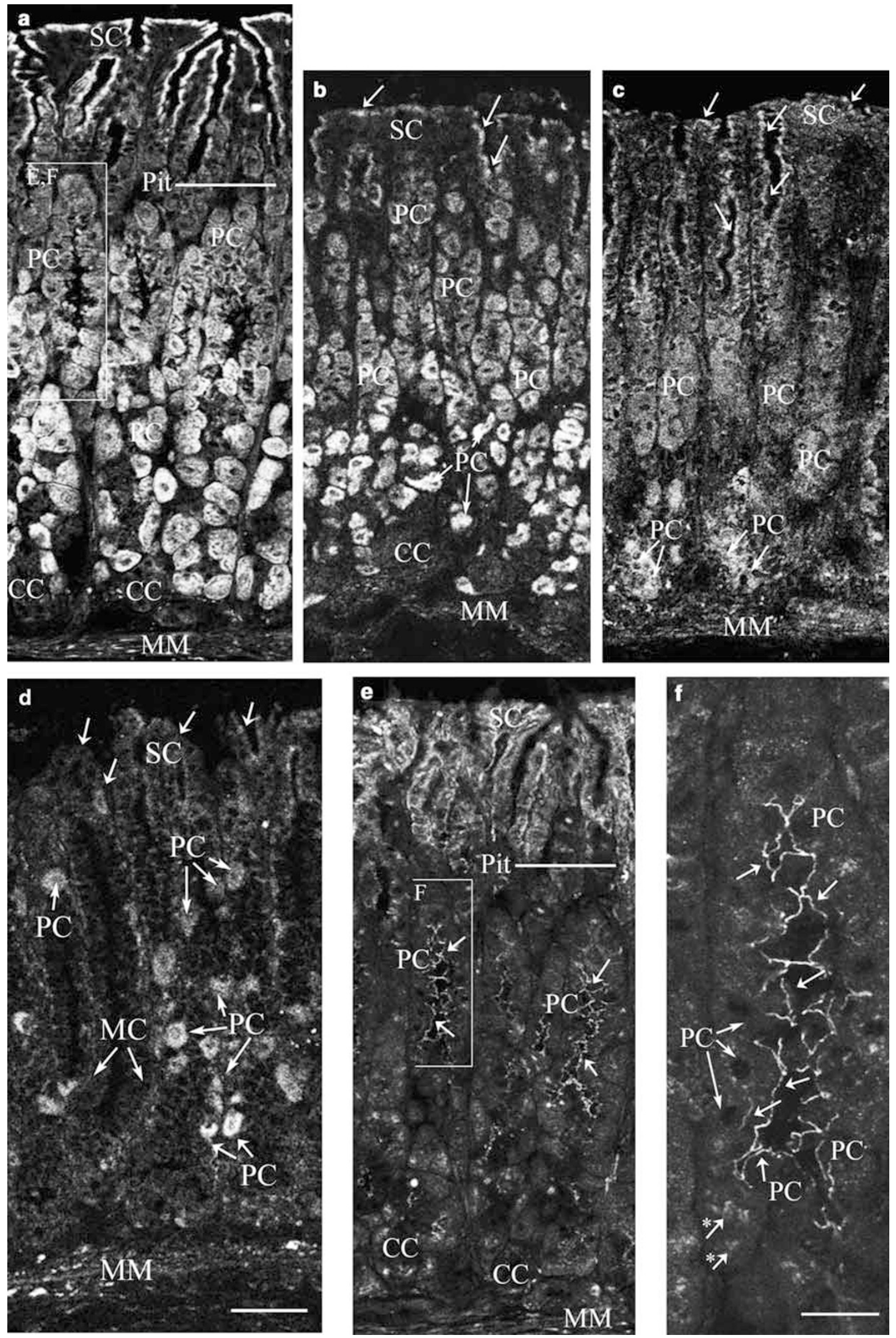
present on western blots (Figure 7). It should be noted that BCL- $\mathrm{X}_{\mathrm{S}}$ was not expressed in either whole stomach (Figure $5 a)$ or in isolated chief cells with no cytokine treatment (control Figure 7).

\section{Expression of ProApoptotic Proteins in the Mouse Gastric Mucosa}

BAK was the only group 1 proapoptotic protein to be highly expressed in the gastric corpus and its localization in the epithelium was limited to surface and pit cells (Figure 8a; Table 1). During HP infection, the expression of BAK was like BCL-2 in Figure 4a and was localized to surface and pit cells (Table 2). BAK was also strongly expressed in inflammatory cells during $H P$ infection (Figure 8a and b; Table 2).

BAX localization was difficult to evaluate because we obtained two results, one with numerous different lots of an affinity purified anti-BAX antibody from Santa Cruz (Figure $9 \mathrm{a}$ and b; Table 1) and another with an unpurified anti-serum to BAX that was purchased from BD Biosciences (not shown). The later antibody confirmed BAX expression in surface, chief, and smooth muscle cells as was described previously by Krajewski et $a l,{ }^{47}$ with the same antibody. With the affinity purified anti-BAX antibody from Santa Cruz, weak staining of surface cells was present although staining of other epithelial cells, like chief cells, could not be demonstrated (Figure 9a; Table 1). BAX expression, however, was strong in smooth muscle cells in the muscularis mucosa, external muscle, and in the lamina propria (Figure 9a; Table 1). During HP infection, the expression of BAX remained weakly expressed in surface and pit cells but was strong in inflammatory cells in the lamina propria and submucosa (Figure 9b).

The only BH3-only protein that was expressed in the gastric corpus was $\mathrm{BAD}$ and its localization was limited to surface, pit, and parietal cells (Figure 10a; Table 1). In surface and pit cells, BAD was highly expressed at the apical cell surface but was also found in the cell cytoplasm (Figure 10a; Table 1). Parietal cells expressed BAD in an ascending gradient, with moderate expression in parietal cells from upper glands and increasingly stronger expression as parietal cells move to the base of gastric glands (Figure 10a; Table 1). At 6 WPI, the expression of BAD in surface cells decreased, especially in the apical location, and in parietal cells it was not different from control (Figure 10b; Table 2). At 12-20 WPI, the expression of BAD in surface cells was present in the cytoplasm but the strong apical expression disappeared (Figure 10c and d; Table 2). BAD in parietal cells from upper glands at 12 WPI was similar to control but parietal cells at the base of gastric glands were in groups with less expression than in control cells at the same location (Figure 10c; Table 2). By 20 WPI, parietal cells still expressed BAD but there were fewer cells along the length of gastric glands so that BAD expression overall decreased accordingly (Figure 10d; Table 2). Inflammatory cells also showed strong expression for BAD during HP infection (Table 2). The same results were obtained with antibodies from Santa Cruz and from Cell Signaling Technology.

\section{PostTranslational Processing of BAD in Tissues from HP-Infected Mice}

Although the studies above demonstrate the localization of BAD protein overall, they do not address whether there is posttranslational modification of BAD during HP infection, in vivo. Thus, we evaluated the expression of phospho$\mathrm{BAD}^{\text {ser112 }}$, which was in the cytoplasm of surface cells and at the apical surface of parietal cells in the middle of gastric glands in control tissues (Figure 10e). Confocal images also suggest intracellular labeling of parietal cells in control tissues (Figure 10f). At $6 \mathrm{WPI}$, the localization of $\mathrm{BAD}^{\mathrm{ser} 112}$ in parietal cells, which were colabeled with $D$. biflorus agglutinin, was similar to control tissues (Figure 11a and c-e). In contrast, areas with atrophy and inflammation irrespective of length of infection (12 or $20 \mathrm{WPI}$ ), showed little expression of $\mathrm{BAD}^{\mathrm{ser} 112}$ at the surface or in parietal cells (Figure $11 \mathrm{~b}$ and $\mathrm{f}-\mathrm{h}$ ). The apical signal in parietal cells was either disrupted significantly or absent when glands were present and individual parietal cells in the mucosa had no specific BAD ${ }^{\text {ser112 }}$ expression (Figure 11b). This result was also confirmed using immunoperoxidase staining methods and paraffin sections (not shown), using the anti-BAD ${ }^{\text {ser112 }}$ antibody (9296, Cell Signaling Technology) that is specific for immunostaining in paraffin sections.

\section{DISCUSSION}

In this study, we demonstrate for the first time that surface, parietal, and chief cells in the gastric mucosa express specific prosurvival and proapoptotic BCL-2 family proteins (Figure 12). Our data show that gastric chief cells constitutively express the prosurvival proteins BCL- $\mathrm{X}_{\mathrm{L}}$ and BCL-2, but do not express a classical apoptosis initiator protein, like $\mathrm{BAD}$ or $\mathrm{BID}$, or executor ligands like BCL- $\mathrm{X}_{\mathrm{S}}, \mathrm{BAX}$, or BAK (Figure 12). We demonstrate that cytokine exposure both reduces viability and induces the expression of BCL- $\mathrm{X}_{\mathrm{S}}$ in chief cells, suggesting that a death stimulus may transcriptionally regulate effector ligand expression to activate the death pathway. Because the transcriptional regulation of $b c l-x$ occurs by glucocorticoid receptor binding to the hormone response element of $b c l-x$, either the concentration of glucocorticoids or of glucocorticoid receptors or receptor activation may be important in regulating the survival of chief cells. Alternatively, NF- $\kappa \mathrm{B}$ activation can significantly increase BCL- $\mathrm{X}_{S}$ expression, so the induced expression of death effector proteins in chief cells may be linked to NF- $\kappa \mathrm{B}$. Gastric surface and pit cells express some BCL-2 for survival, but express $\mathrm{BAD}$ as an apoptotic initiator protein and BAK as an executor ligand (Figure 12). These results suggest that the regulation of surface and pit cell survival is by growth factors or their receptors, which posttranslationally modify the phosphorylation status of BAD. Parietal cells constitutively 

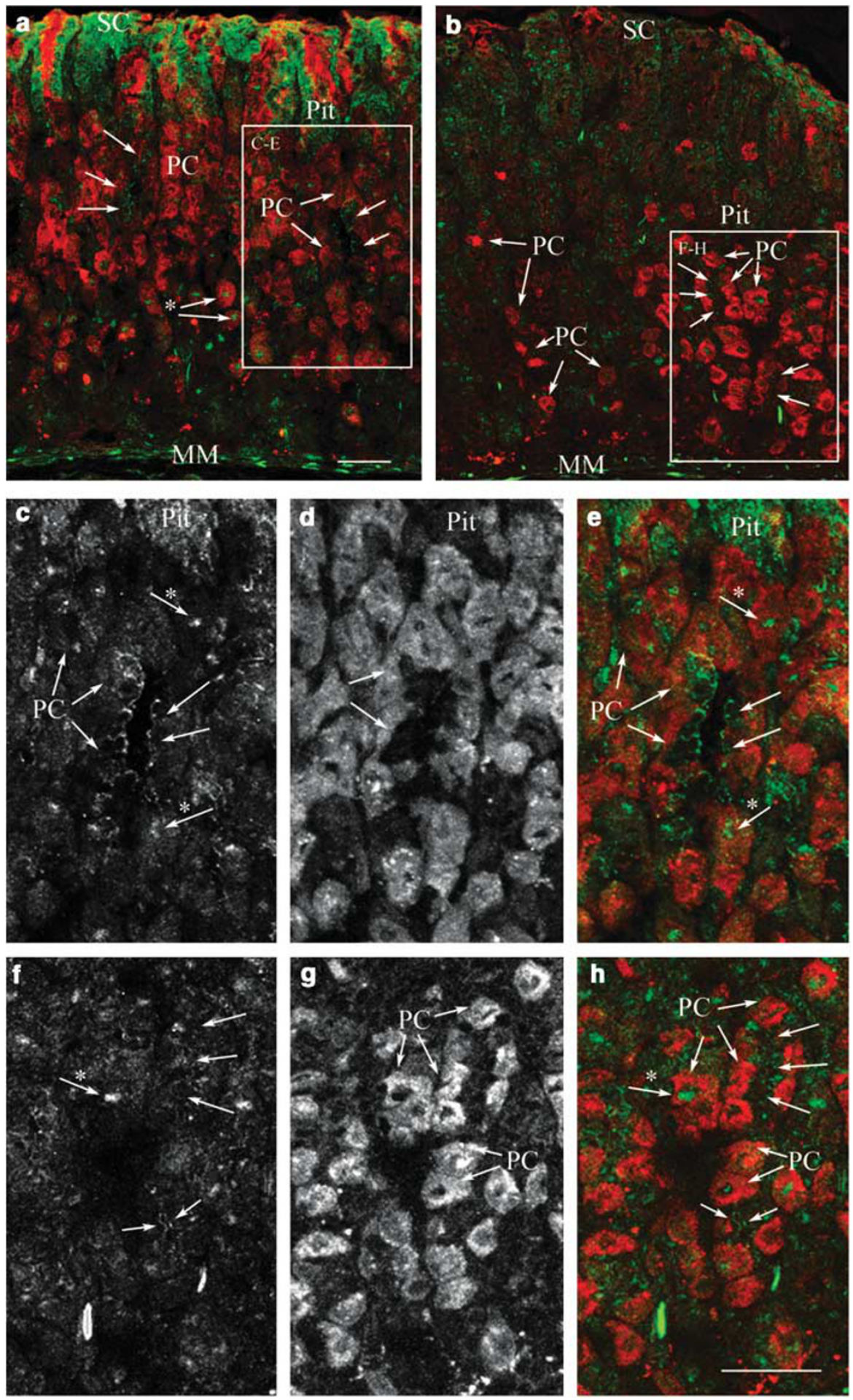

Figure 11 Expression of BAD ser112 in sections from mice at 6 WPI (a, c-e) and 12 WPI (b, f-h). (a) The expression of BAD ${ }^{\text {ser112 }}$ at 6 WPI in HP-infected mice was similar to sham control (Figure 10) in areas with little inflammation and with a normal histology as shown in Figure $1 \mathrm{c}$ and d. (c-e) Expression of $B A D^{\text {ser112 }}$ in samples (from the boxed region in a) labeled with anti-BAD ${ }^{\text {ser112 }}$ antibody (c), Dolichos biflorus agglutinin for parietal cells (PCs) (d), and merged images (e), where green is BAD ${ }^{\text {ser112 }}$ and red is $D$. biflorus agglutinin. Note that the apical surface of PCs from the upper neck had bright signal localized to the apical cytoplasm (arrows) and that cytoplasmic staining was also present $\left.{ }^{(}\right)$. (b) The expression of BAD ${ }^{\text {ser } 112}$ at 12 WPI in tissues from HP-infected mice, where inflammation was considerable in the lamina propria and submucosa (like in Figure $1 \mathrm{~h}$ ). Note that the expression of BAD ${ }^{\text {ser112 }}$ was significantly reduced in SCs and at the apical surface of PCs (arrows). (f-h) Expression of BAD ${ }^{\text {ser112 }}$ in samples (from the boxed region in $\mathbf{b}$ ) labeled with anti-BAD ${ }^{\text {ser112 }}$ antibody $(\mathbf{f}), D$. biflorus agglutinin for PCs $(\mathbf{g})$, and merged images $(\mathbf{h})$, where green is BAD $D^{\text {ser112 }}$ and red is $D$. biflorus agglutinin. Note that the apical surface of PCs have little apical signal (arrows). MM, muscularis mucosa; PCs, parietal cells; SCs, surface cells. Bar in a represents the magnification for $\mathbf{a}$, $\mathbf{b}$ and is $100 \mu \mathrm{m}$. Bars in c-f are $50 \mu \mathrm{m}$. 


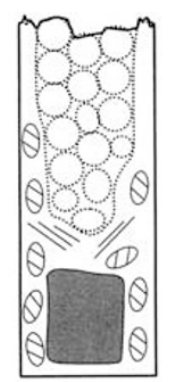

\section{Surface and Pit cells APOPTOSIS SURVIVAL

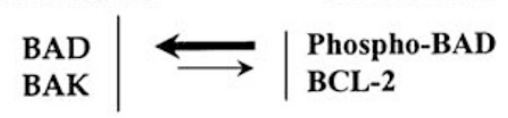

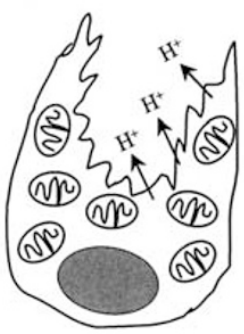

$\underline{\text { Parietal Cells }}$

APOPTOSIS SURVIVAL

BAD

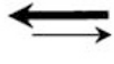

Phospho-BAD
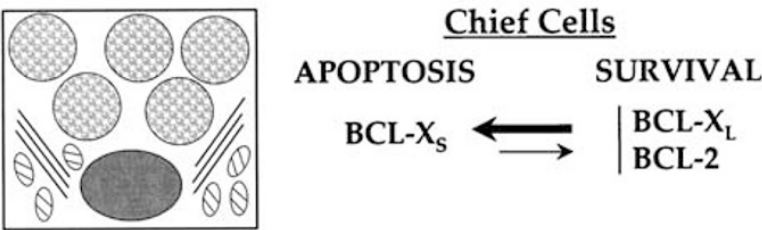

Figure 12 Schematic diagram of the cell-specific expression of BCL-2 family proteins in gastric surface, parietal, and chief cells that are predicted to facilitate apoptosis during HP infection in mice.

express high levels of BAD, as well, suggesting that the regulation of parietal cell survival may also occur by pathways that modify the phosphorylation status of BAD.

Although the expression of BAD was similar in all gastric surface and pit cells, BAD expression in parietal cells showed a pit to base gradient suggesting that BAD is transcriptionally regulated in parietal cells. This is a unique finding, because $\mathrm{BAD}$ is transcriptionally regulated only in development, when it is thought to be important for apoptotic events that are specific for neuronal degeneration from embryonic day 19 to 2 weeks after gestation. ${ }^{48}$ In this study, BAD expression was greater in older parietal cells that are destined to die at the base of gastric glands, ${ }^{49,50}$ suggesting that increasing the concentration of BAD be involved in the turnover of parietal cells. However, Hamner et $a l^{51}$ showed that significantly increasing $\mathrm{BAD}$ expression in neurons could have a protective effect under certain conditions and kill cells under others. Thus, the high level of BAD expression in parietal cells is unclear with regard to function. In the present report, phosopho-BAD ${ }^{\text {ser112 }}$ protein localized to parietal cells in the middle of gastric glands, which is the localization of parietal cells actively secreting acid. ${ }^{49}$ This finding is interesting, because parietal cells activate AKT phosphorylation, ${ }^{52}$ and PKA and other signaling molecules such as MAPK and ERK1/2 are generated, ${ }^{53,54}$ which are the signals necessary to phosphorylate $\mathrm{BAD}$. If $\mathrm{BAD}$ is used in a classical sense to support the survival and death of parietal cells, these results suggest that the posttranslational processing of $\mathrm{BAD}$, and thus long-term cell survival, may be coupled to gastric acid secretion. Longterm inhibition of acid secretion with omeprazole or by targeted deletion of the sodium hydrogen exchanger isoform 2 results in the degeneration of parietal cells and to an increase in parietal cell turnover, ${ }^{55,56}$ supporting the idea that a link may exist between BAD phosphorylation, cell survival, and acid secretion. Because our results showed that the expression of phosopho-BAD ${ }^{\text {ser112 }}$ was significantly reduced in parietal cells during $H P$ infection, it is possible that $H P$ infection alters the posttranslational processing of $\mathrm{BAD}$ in gastric parietal cells to increase the rate of parietal cell turnover during infection. In contrast to surface and neck cells, parietal cells did not express other BCL-2 family prosurvival or proapoptotic executor proteins that we analyzed (Figure 12). We did not include MCL-1, A-1, BOO/DIVA, and BCL-B in our protocol because these proteins have been found to be expressed almost exclusively in hematopoetic cells. Thus, the way in which apoptosis is executed cannot be predicted and further studies would be needed to define this important process in parietal cells.

Although BAX is thought to be constitutively expressed in gastric chief and parietal cells, ${ }^{47}$ we were unable to confirm these results using numerous different lots of an affinity purified antibody. Other than technical differences in the fixation protocol, antibody source, and antibody concentration, it is unclear why the expression of BAX is different when different antibodies are used. Although our results demonstrate that BAX is not constitutively expressed in gastric epithelial cells, we cannot rule out the possibility that the induction of BAX closely parallels the initiation of cell death and the long span of time between in vivo samples in our study was inadequate to capture this short-term event. This idea is supported by studies from Neu et al, ${ }^{8}$ who showed that BAX was expressed in fractions of isolated and highly purified chief cells and at a greater concentration in chief cells after $48 \mathrm{~h}$ in culture. The same results were obtained for BAX expression in isolated and highly purified parietal cells and in cultured parietal cells. ${ }^{8}$ BAX expression in this study increased overall in tissue sections during $H P$ infection because there was an increase in the number of inflammatory cells that strongly expressed BAX. This result is consistent with the known expression of BAX in lymphoid and myeloid cells of the immune system ${ }^{57-59}$ and may explain why BAX expression increased significantly in patient biopsy samples that were probed by western blotting techniques. ${ }^{60}$ Our immunostaining results showed that BAK is also highly expressed in gastric surface and pit cells and suggests that BAK:BAK complexes could be involved in the execution of apoptosis in these cells. Further studies would be required to determine the apoptosis executor proteins in parietal and chief cells.

Because chief cells express high levels of BCL- $\mathrm{X}_{\mathrm{L}}$ and induce $\mathrm{BCL}-\mathrm{X}_{\mathrm{S}}$ when provided a toxic stimulus (cytokine 
exposure), our data suggest that chief cells transcriptionally regulate $b c l-x$ gene expression to modulate the ratio of BCL- $\mathrm{X}_{\mathrm{L}}$ to BCL- $\mathrm{X}_{\mathrm{S}}$ and could use a classical apoptotic pathway if an initiator pathway can be defined. Because we did not examine all possible cell death and survival proteins, including the initiator proteins BLK, BMF, and NOXA/ PUMA that are found mostly in hematopoetic and cancer cells, other proteins may be expressed to facilitate the death of chief cells in general and during disease. In this study, the expression of BCL- $\mathrm{X}_{\mathrm{L}}$ in chief cells was accompanied by BCL-2, which our results showed is only weakly expressed in gastric epithelial cells. The expression of BCL-2 reported here was the same as in rat stomach, where chief cells had the greatest level of expression when compared to other epithelial cells in the corpus. ${ }^{8}$ The combination of BCL- $\mathrm{X}_{\mathrm{L}}$ and BCL-2 is known to strongly inhibit apoptosis, and is expressed only in specific populations of cells that are long-lived. ${ }^{23}$ Because chief cells fit into this category, living 6 months or more, ${ }^{50,61}$ it seems reasonable to conclude that chief cells are programmed to express $\mathrm{BCL}-\mathrm{X}_{\mathrm{L}} / \mathrm{BCL}-2$ to regulate their long-term survival, in vivo.

BCL-2 and BCL- $\mathrm{X}_{\mathrm{L} / \mathrm{S}}$ were also expressed in SPEM cells during $H P$ infection. It is well established that mice infected with either HP or HF develop corpus atrophy and SPEM, which occurs after mature chief and parietal cells die during infection. ${ }^{1,62,63}$ Although the lineage of SPEM cells is controversial, it is notable that SPEM cells express chief cellspecific survival proteins at 12 and 20 WPI.

In conclusion, we provide the first evidence that cell-specific PCD pathways regulate the survival and death of gastric epithelial cells. Although the expression of BCL-2 family proteins in surface and pit cells are consistent with the use of classical apoptosis pathways, the protein expression in chief and parietal cells suggests that either unique or nonconventional pathways for survival and death are employed. Such insights offer a new strategy for further investigation into mechanisms that regulate PCD in gastric epithelial cells, with special emphasis on those pathways now known to exist in each individual cell type.

\section{ACKNOWLEDGEMENTS}

We acknowledge the help of Dr Barbara Sheppard in histological scoring of tissues from control and HP-infected mice. This work was supported by National Institutes of Health Grants R01 DK-15681 (SJ Hagen), P30 DK-34854 (Harvard Digestive Diseases Center), R01 CA-67463 (JG Fox), and R01 Al/RR-37750 (JG Fox). Dr Tashima received travel support from a scholarship awarded by the Japanese Research Foundation for Clinical Pharmacology.

1. Wang TC, Goldenring JR, Dangler $C$, et al. Mice lacking secretory phospholipase $\mathrm{A}_{2}$ show altered apoptosis and differentiation with Helicobacter felis infection. Gastroenterology 1998;114:675-689.

2. Karabay G, Nacar A, Can F, et al. Apoptosis and proliferation in gastric epithelium due to Helicobacter pylori: an immunohistochemical and ultrastructural study. Acta Gastroenterol Belg 2006;69:191-196.
3. Fu HY, Asahi K, Hayashi Y, et al. East Asian-type Helicobacter pylori cytotoxin-associated gene A protein has a more significant effect on growth of rat gastric mucosal cells than the western type. J Gastroenterol Hepatol 2007;22:355-362.

4. Cui G, Takaishi S, Ai W, et al. Gastrin-induced apoptosis contributes to carcinogenesis in the stomach. Lab Invest 2006;86:1037-1051.

5. Suzuki $H$, Yanaka A, Shibahara T, et al. Ammonia-induced apoptosis is accelerated at higher $\mathrm{pH}$ in gastric surface cells. Am J Physiol Gastrointest Liver Physiol 2002;283:G986-G995.

6. Nakamura E, Hagen SJ. Role of glutamine and arginase in protection against ammonia-induced cell death in gastric epithelial cells. Am J Physiol Gastrointest Liver Physiol 2002;283:1264-1275.

7. Hagen SJ, Takahashi S, Jansons R. The role of vacuolation in the death of gastric epithelial cells. Am J Physiol Cell Physiol 1997;272:C48-C58.

8. Neu B, Herrmuth $\mathrm{H}$, Ernst F, et al. Differential expression of CD95, BCl-2, and Bax in rat gastric chief and parietal cells. Microsc Res Tech 2001;53:377-388.

9. Neu B, Randlkofer P, Euhoffer $M$, et al. Helicobacter pylori induces apoptosis of rat gastric parietal cells. Am J Physiol Gastrointest Liver Physiol 2002;283:G309-G318.

10. Neu B, Puschmann AJ, Mayerhofer A, et al. TNF- $\alpha$ induces apoptosis of parietal cells. Biochem Pharmacol 2003;65:1755-1760.

11. Krantic S, Mechawar N, Reix S, et al. Apoptosis-inducing factor: a matter of neuron life and death. Prog Neurobiol 2007;81: 179-196.

12. Bouillet $\mathrm{P}$, Strasser $\mathrm{A}$. BH3-only proteins-evolutionarily conserved proapoptotic $\mathrm{BCl}-2$ family members essential for initiating programmed cell death. J Cell Sci 2002;115:1567-1574.

13. Puthalakath $\mathrm{H}$, Strasser A. Keeping killers on a tight leash: transcriptional and post-translational control of the pro-apoptotic activity of BH3-only proteins. Cell Death Differ 2002;9:505-512.

14. Danial NN, Korsmeyer SJ. Cell death: critical control points. Cell 2004;116:205-219.

15. Youle RJ. Cellular demolition and the rules of engagement. Science 2007;315:776-777.

16. Letai $A$, Bassik MC, Walensky LD, et al. Distinct BH3 domains either sensitize or activate mitochondrial apoptosis, serving as prototype cancer therapeutics. Cancer Cell 2002;2:183-192.

17. Willis SN, Fletcher Jl, Kaufmann T, et al. Apoptosis initiated when BH3 ligands engage multiple $\mathrm{BCl}-2$ homologs, not Bax or Bak. Science 2007;315:856-859.

18. Sevilla $L$, Zaldumbide $A$, Pognonec $P$, et al. Transcriptional regulation of the $b c l-x$ gene encoding the anti-apoptotic Bcl- $x_{L}$ protein by Ets, Rel/NF- $\kappa$ B, STAT, and AP1 transcription factor families. Histol Histopathol 2001;16:595-601.

19. Minn AJ, Boise $\mathrm{LH}$, Thompson $\mathrm{CB}$. BCl- $\mathrm{X}_{\mathrm{S}}$ antagonizes the protective effects of BCL-XL. J Biol Chem 1996;271:6306-6312.

20. Pecci A, Viegas LR, Baranao JL, et al. Promoter choice influences alternative splicing and determines the balance of isoforms expressed from the mouse $b c \mathrm{l}-X$ gene. J Biol Chem 2001;276: 21062-21069.

21. Kim R. Unknotting the roles of $\mathrm{BCl}-2$ and $\mathrm{BCl}-\mathrm{x}_{\mathrm{L}}$ in cell death. Biochem Biophys Res Commun 2005;333:336-343.

22. Kharbanda S, Pandey $\mathrm{P}$, Schofield $\mathrm{L}$, et al. Role for $\mathrm{BCl}-\mathrm{X}_{\mathrm{L}}$ as an inhibitor of cytosolic cytochrome $c$ accumulation in DNA damage-induced apoptosis. Proc Natl Acad Sci USA 1997;94:6939-6942.

23. Boise LH, Gonzalez-Garcia M, Postema CE, et al. bcl-x, a bcl-2-related gene that functions as a dominant regulator of apoptotic cell death. Cell 1993;74:597-608.

24. Viegas LR, Vincent GP, Baranao JL, et al. Steroid hormones induce $b c l-X$ gene expression through direct activation of distal promoter P4. J Biol Chem 2004;279:9831-9839.

25. Pecci A, Scholz A, Pelster D, et al. Progestins prevent apoptosis in a rat endometrial cell line and increase the ratio of $b c l-x_{L}$ to $b c l-x_{s}$. J Biol Chem 1997;272:11791-11798.

26. Amsterdam A, Sasson R. The anti-inflammatory action of glucocorticoids is mediated by cell type specific regulation of apoptosis. Mol Cell Endocrinol 2002;189:1-9.

27. Sakamoto T, Repasky WT, Chen J, et al. Down-regulation of bcl- $X_{S}$ gene expression in rat thymocytes by dexamethasone. Biochem Biophys Res Commun 1995;215:511-516.

28. Gascoyne DM, Kypta RM, Vivanco MDM. Glucocorticoids inhibit apoptosis during fibrosarcoma development by transcriptionally activating BCl- $\mathrm{K}_{\mathrm{L}}$. J Biol Chem 2003;278:18022-18029. 
29. Glasgow JN, Qin JX, Rassin D, et al. Transcriptional regulation of the $B C L-X$ gene by NF-kB is an element of hypoxic response in the rat brain. Neurochem Res 2001;26:647-659.

30. Gilmore AP, Valentijn AJ, Wang $P$, et al. Activation of BAD by therapeutic inhibition of epidermal growth factor receptor and transactivation by insulin-like growth factor receptor. J Biol Chem 2003;277:27643-27650.

31. del Peso L, Gonzalez-Garcia M, Page C, et al. Interleukin-3-induced phosphorylation of BAD through the protein kinase Akt. Science 1997;278:687-689.

32. Zhou X-M, Liu Y, Payne G, et al. Growth factors inactivate the cell death promotor BAD by phosphorylation of its $\mathrm{BH} 3$ domain on $\mathrm{Ser}^{155}$. J Biol Chem 2000;275:25046-25051.

33. Harada $H$, Becknell $B$, Wilm $M$, et al. Phosphorylation and inactivation of BAD by mitochondria-anchored protein kinase A. Mol Cell 1999:3:413-422.

34. Fang X, Yu S, Eder A, et al. Regulation of BAD phosphorylation at serine 112 by Ras-mitogen-activated protein kinase pathway. Oncogene 1999;18:6635-6640.

35. Datta SR, Dudek H, Tao X, et al. AKT phosphorylation of BAD couples survival signals to the cell-intrinsic death machinery. Cell 2003;91: 231-241.

36. Grethe S, Porn-Ares MI. p38 MAPK regulates phosphorylation of BAD via PP2A-dependent suppression of the MEK1/2-ERK1/2 survival pathway in TNF-alpha induced endothelial apoptosis. Cell Signal 2006;18:531-540.

37. Ray RM, Bhattacharya S, Johnson LR. Protein phosphatase $2 \mathrm{~A}$ regulates apoptosis in intestinal epithelial cells. J Biol Chem 2005;280: 31091-31100.

38. Yang $E$, Zha J, Jockel J, et al. BAD, a heterodimeric partner for BCL- $\mathrm{X}_{\mathrm{L}}$ and BCL-2, displaces BAX and promotes cell death. Cell 1995;80: 285-291.

39. Lee A, O'Rourke J, DeUngria MC, et al. A standardized mouse model of Helicobacter pylori infection: introducing the Sydney strain. Gastroenterology 1997;112:1386-1397.

40. Fox JG, Dangler C, Taylor NS, et al. High-salt diet induces gastric epithelial hyperplasia and parietal cell loss, and enhances Helicobacter pylori colonization in C57BL/6 mice. Cancer Res 1999;59:4823-4828.

41. Hagen SJ, Trier JS, Dambrauskas R. Exposure of the rat small intestine to raw kidney beans results in reorganization of absorptive cell microvilli. Gastroenterology 1994;106:73-84.

42. Chew CS, Brown MR. Release of intracellular $\mathrm{Ca}^{2+}$ and elevation of inositol triphosphate by secretagogues in parietal and chief cells isolated from rabbit gastric mucosa. Biochim Biophys Acta 1986;888:116-125.

43. Chew CS. CAMP technologies, functional correlates in gastric parietal cells. Methods Enzymol 1990;191:640-661.

44. Chen MC, Lee AT, Karnes WE, et al. Paracrine control of gastric epithelial cell growth in culture by transforming growth factor- $\alpha$. Am J Physiol Gastrointest Liver Physiol 1993;264:G390-G396.

45. Chen MC, Chang A, Buhl T, et al. Apical acidification induces paracellular injury in canine gastric mucosal monolayers. Am J Physiol Gastrointest Liver Physiol 1994;267:G1012-G1020.
46. Chew CS. Parietal cell culture: new models and directions. Annu Rev Physiol 1994;56:445-461.

47. Krajewski S, Krajewska M, Shabaik A, et al. Immunohistochemical determination of in vivo distribution of Bax a dominant inhibitor of $\mathrm{BCl}$ 2. Am J Pathol 1994;145:1323-1336.

48. Shimohama S, Fujimoto S, Sumida Y, et al. Differential expression of rat brain $\mathrm{Bcl}-2$ family proteins in development and aging. Biochem Biophys Res Commun 1998;252:92-96.

49. Karam SM, Yao X, Forte JG. Functional heterogeneity of parietal cells along the pit-gland axis. Am J Physiol 1997;272:G161-G171.

50. Karam SM. Dynamics of epithelial cells in the corpus of the mouse stomach IV. Bidirectional migration of parietal cells ending in their gradual degeneration and loss. Anat Rec 1993;236:314-332.

51. Hamner S, Arumae U, Li-Ying Y, et al. Functional characterization of two splice variants of rat BAD and their interaction with BCL-W in sympathetic neurons. Mol Cell Neurosci 2001;17:97-106.

52. Todisco A, Pausawasdi N, Ramamoorthy S, et al. Functional role of protein kinase B/Akt in gastric acid secretion. J Biol Chem 2001;276:46436-46444.

53. Urushidani T, Forte JG. Signal transduction and activation of acid secretion in the parietal cell. J Membr Biol 1997;159:99-111.

54. Nakamura K, Zhou C-J, Parente JA, et al. Parietal cell MAP kinases: multiple activation pathways. Am J Physiol 1996;271:G640-G649.

55. Karam SM, Forte JG. Inhibiting gastric $\mathrm{H}^{+}-\mathrm{K}^{+}$-ATPase activity by omeprazole promotes degeneration and production of parietal cells. Am J Physiol 1994;266:G758.

56. Schultheis PJ, Clarke LL, Meneton $\mathrm{P}$, et al. Targeted disruption of the murine $\mathrm{Na}^{+} / \mathrm{H}^{+}$exchanger isoform 2 gene causes reduced viability of gastric parietal cells and loss of net acid secretion. J Clin Invest 1998;101:1243-1253.

57. Marsden VS, Strasser A. Control of apoptosis in the immune system: $\mathrm{Bcl}-2$, BH3-only proteins and more. Annu Rev Immunol 2003;21: 71-105.

58. Lindsten T, Ross AJ, King A, et al. The combined functions of proapoptotic $\mathrm{Bcl}-2$ family members Bak and Bax are essential for normal development of multiple tissues. Mol Cell 2000;6: 1389-1399.

59. Opferman JT, Korsmeyer SJ. Apoptosis in the development and maintenance of the immune system. Nat Immunol 2003;4: 410-415.

60. Konturek PC, Pierzchalski P, Konturek SJ, et al. Helicobacter pylori induces apoptosis in gastric mucosa through an upregulation of bax expression in humans. Scand J Gastroenterol 1999;34:375-383.

61. Karam SM, Leblond CP. Dynamics of epithelial cells in the corpus of the mouse stomach. III. Inward migration of neck cells followed by progressive transformation into zymogenic cells. Anat Rec 1993;236:297-313.

62. Fox JG, Wang $T C$, Robers $A B$, et al. Host and microbial constituents influence Helicobacter pylori-induced cancer in a murine model of hypergastrinaemia. Gastroenterology 2003;124:1879-1890.

63. Fox JG, Li X, Cahill RJ, et al. Hypertrophic gastropathy in Helicobacter felis-infected wild-type C57BL/6 mice and p53 hemizygous transgenic mice. Gastroenterology 1996;110:155-166. 